\title{
Ship-borne aerosol profiling with lidar over the Atlantic Ocean: from pure marine conditions to complex dust-smoke mixtures
}

\author{
Stephanie Bohlmann ${ }^{1, \text { a }}$, Holger Baars ${ }^{1}$, Martin Radenz ${ }^{1}$, Ronny Engelmann ${ }^{1}$, and Andreas Macke ${ }^{1}$ \\ ${ }^{1}$ Leibniz Institute for Tropospheric Research, Permoserstraße 15, 04318 Leipzig, Germany \\ ${ }^{a}$ now at: Finnish Meteorological Institute, P.O. Box 1627, 70211, Kuopio, Finland
}

Correspondence: Stephanie Bohlmann (stephanie.bohlmann@fmi.fi)

Received: 19 January 2018 - Discussion started: 28 February 2018

Revised: 8 June 2018 - Accepted: 8 June 2018 - Published: 9 July 2018

\begin{abstract}
The multi-wavelength Raman lidar Polly ${ }^{\mathrm{XT}}$ has been regularly operated aboard the research vessel Polarstern on expeditions across the Atlantic Ocean from north to south and vice versa. The lidar measurements of the RV Polarstern cruises PS95 from Bremerhaven, Germany, to Cape Town, Republic of South Africa (November 2015), and PS98 from Punta Arenas, Chile, to Bremerhaven, Germany (April/May 2016), are presented and analysed in detail. The latest set-up of Polly ${ }^{\mathrm{XT}}$ allows improved coverage of the marine boundary layer (MBL) due to an additional near-range receiver.

Three case studies provide an overview of the aerosol detected over the Atlantic Ocean. In the first case, marine conditions were observed near South Africa on the autumn cruise PS95. Values of optical properties (depolarisation ratios close to zero, lidar ratios of $23 \mathrm{sr}$ at 355 and $532 \mathrm{~nm}$ ) within the MBL indicate pure marine aerosol. A layer of dried marine aerosol, indicated by an increase of the particle depolarisation ratio to about $10 \%$ at $355 \mathrm{~nm}(9 \%$ at $532 \mathrm{~nm})$ and thus confirming the non-sphericity of these particles, could be detected on top of the MBL. On the same cruise, an almost pure Saharan dust plume was observed near the Canary Islands, presented in the second case. The third case deals with several layers of Saharan dust partly mixed with biomass-burning smoke measured on PS98 near the Cabo Verde islands. While the MBL was partly mixed with dust in the pure Saharan dust case, an almost marine MBL was observed in the third case.

A statistical analysis showed latitudinal differences in the optical properties within the MBL, caused by the downmixing of dust in the tropics and anthropogenic influences in the northern latitudes, whereas the optical properties of the MBL in the Southern Hemisphere correlate with typical ma-
\end{abstract}

rine values. The particle depolarisation ratio of dried marine layers ranged between 4 and $9 \%$ at $532 \mathrm{~nm}$.

Night measurements from PS95 and PS98 were used to illustrate the potential of aerosol classification using lidar ratio, particle depolarisation ratio at 355 and $532 \mathrm{~nm}$, and Ångström exponent. Lidar ratio and particle depolarisation ratio have been found to be the main indicator for particle type, whereas the Ångström exponent is rather variable.

\section{Introduction}

Aerosols, solid or liquid particles dispersed in air, play an important role in the Earth's climate system. By scattering and absorbing solar and terrestrial radiation, aerosols highly affect the radiation fluxes and thus the radiative budget. In addition to this direct aerosol radiative forcing, aerosols also modify the microphysical properties of clouds by acting as cloud condensation or ice nuclei and thereby influence the radiative budget indirectly (Twomey, 1977). Furthermore, the presence of aerosol particles influences the lifetime of clouds (Albrecht, 1989).

As the impact of aerosols on the climate system is various, it has to be considered in climate modelling to receive accurate results, which is, however, challenging because not all aerosol types contribute to the aerosol radiative forcing in the same way (Ocko et al., 2012; Myhre et al., 2013) and, additionally, information about global aerosol distributions is rare due to its high spatial and temporal variability. Thus, uncertainties in aerosol forcing and the poor understanding of aerosol-cloud interactions represent a large uncertainty in current climate models despite the progress in observing 
and modelling climate-relevant aerosol properties and atmospheric distributions in the last years (IPCC, 2013). More information about the horizontal and vertical distribution of different aerosol types is needed to further improve climate modelling and prediction and to understand its complex interaction with the atmosphere. Therefore, the observation of the spatio-temporal aerosol distribution is an objective in a wide range of research projects. Apart from satellite observations, most projects concentrate on observations over land. Since about $70 \%$ of the Earth's surface is covered by water, aerosols and their distribution have to be investigated over the oceans as well, even though the investigation is more challenging.

Light detection and ranging (lidar) represents a key method to investigate vertically resolved aerosol properties. Measurements with high spatial and temporal resolution and under ambient conditions are possible up to an altitude of $100 \mathrm{~km}$ depending on the lidar set-up (Wandinger, 2005). Many institutes all over the world are performing lidar measurements and create networks as shown in the 178th GAW report (Bösenberg et al., 2007). While the Northern Hemisphere is well covered with observation sites, there are only a few lidar stations in the Southern Hemisphere. Over the oceans, aerosol measurements are rare and to our knowledge no regular, vertically resolved measurements allowing aerosol typing are performed from ground. To close this gap, the OCEANET project was initiated to investigate the transport of material and energy between the ocean and atmosphere. The OCEANET project is a collective project of several German research institutes and combines oceanographic measurements with atmospheric observations on a ship-borne platform. It is regularly deployed on research vessels (RV), such as the RV Polarstern. One instrument within the OCEANET facility is the portable and automated Raman and polarisation lidar system Polly $\mathrm{XT}$ (Althausen et al., 2009; Engelmann et al., 2016). This lidar system allows aerosol typing and investigations of the atmosphere up to about $20 \mathrm{~km}$.

The first cruise with Polly ${ }^{\mathrm{XT}}$ on the RV Polarstern took place in 2009. Since then, eight cruises have been performed on the RV Polarstern between Bremerhaven and Punta Arenas and between Bremerhaven and Cape Town until summer 2016, covering almost the whole north-south extension of the Atlantic Ocean. Typical cruise tracks are shown in Fig. 1. These measurements therefore represent a valuable contribution to the knowledge of distribution and variability of aerosols over the Atlantic. The first cruises have already been analysed by Kanitz et al. (2013, 2014). Saharan dust and mixtures of biomass-burning smoke and dust were observed at the west coast of North Africa as well as Patagonian dust over the South Atlantic. The lidar system used for these measurements did not cover the lowermost $500-800 \mathrm{~m}$ of the troposphere; therefore, the marine boundary layer (MBL) could not be investigated. However, the investigation of optical and microphysical properties of pure marine aerosol is

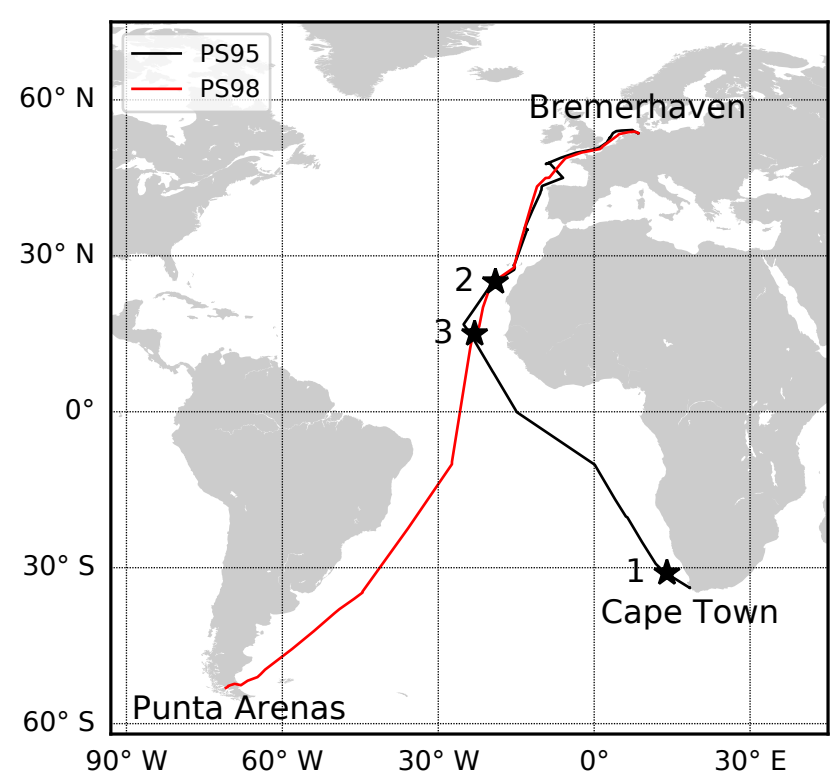

Figure 1. RV Polarstern cruises with Polly $\mathrm{XT}$ aboard. Cruise tracks are taken from the Pangaea database (https://www.pangaea.de/ expeditions/cr.php/Polarstern, last access: 24 February 2017). Black stars mark the location of the case studies presented in Sect. 3.2.

essential, as this knowledge is used in retrievals for spaceborne instruments like CALIPSO (Cloud-Aerosol Lidar and Infrared Pathfinder Satellite Observation, Omar et al., 2009), which are able to investigate aerosols globally and thus also over the ocean but with limited capabilities. As land-based observations of aerosols mostly do not allow observation of pure marine conditions, only ship-borne observations are suited to make detailed studies of the marine environment found over the oceans. Polly ${ }^{\mathrm{XT}}$ has been further developed since these first cruises. The latest set-up (Engelmann et al., 2016) possesses now, in addition to the original capabilities, four near-range channels and depolarisation measurements at two wavelengths. Due to a new near-range detection unit, the height of complete overlap between the receiver field of view and laser beam was reduced from about 1500 to $120 \mathrm{~m}$ and now enables measurements close to the lidar. Observations with this advanced lidar set-up over the ocean offer the unique opportunity to investigate the MBL in addition to the aerosol conditions in the free troposphere, which was not possible until now. In this paper three case studies covering typical aerosol conditions during the cruises PS95 and PS98 will be discussed to investigate the whole atmospheric column above the ship. A statistical analysis is presented contrasting the zonal dependence of the aerosol conditions over the Atlantic. In Sect. 2 the Raman lidar Polly ${ }^{\mathrm{XT}}$, the aerosol characterisation by optical properties, and the respective data analysis methods are briefly introduced. Section 3 gives an overview of the lidar measurements during PS95 and PS98, discusses the case studies, and shows a statistical analysis of both cruises. In Sect. 4 the results are summarised. 


\section{Instrument and methods}

The lidar measurements during the Atlantic cruises were performed with the portable Raman and polarisation lidar system Polly ${ }^{\mathrm{XT}}$-OCEANET. A detailed description of the optical set-up can be found in Althausen et al. (2009) and Engelmann et al. (2016).

The latest set-up of Polly XT_OCEANET enables the measurement of backscatter coefficient profiles at 355, 532, and $1064 \mathrm{~nm}$ and extinction coefficient profiles at 355 and $532 \mathrm{~nm}$. Furthermore, depolarisation measurements at 355 and $532 \mathrm{~nm}$ are possible. A second detection unit enables measurements near the lidar at 355 and $532 \mathrm{~nm}$ and the corresponding Raman wavelengths 387 and $607 \mathrm{~nm}$ down to about $120 \mathrm{~m}$ above the lidar (Engelmann et al., 2016).

The backscatter coefficient $\beta$ describes the amount of the light backscattered to the lidar at an angle of $180^{\circ}$. The attenuation of the emitted light due to absorption and scattering on the way through the atmosphere is described by the extinction coefficient $\alpha$. The ratio of extinction to backscatter coefficient is called lidar ratio $S$. As the extinction is the attenuation of light due to scattering and absorption, the lidar ratio can be used to determine the absorbing capacity of the backscattering particles. Absorbing aerosols like soot have a much higher lidar ratio than non-absorbing particles like sea salt (Müller et al., 2007; Groß et al., 2011). The relationship of the backscatter or extinction coefficient at two wavelengths $\lambda_{1}, \lambda_{2}$ as a function of the ratio of these wavelengths is given by the backscatter or extinction-related Ångström exponent $\AA$ (Ångström, 1929). It indicates the particle size. Small particles show a strong wavelength dependence; thus, $\AA$ is greater than 1 . In contrast, the scattering on large particles is almost wavelength independent and $\AA$ is approximately zero (Eck et al., 1999; Müller et al., 2007; Baars et al., 2016).

The emitted laser light of the Polly ${ }^{\mathrm{XT}}$ lidar is linear polarised. In the atmosphere, the light is depolarised when scattered by non-spherical particles like dust or ice crystals. The detected light therefore contains a cross-polarised component in addition to the parallel-polarised light and can be detected separately. The ratio of cross-polarised to parallelpolarised light backscattered by particles is called particle depolarisation ratio. If the particles are mainly spherical, the particle depolarisation ratio is about zero because the linear polarised light has been returned to the lidar without changing the polarisation state. Non-spherical particles show higher depolarisation ratios. This quantity therefore enables the determination of the particle sphericity.

Ångström exponent, lidar ratio, and depolarisation ratio are indicators of the aerosol type. By knowing typical values of the lidar ratio, Ångström exponent, and particle depolarisation ratio, the dominant particle type can be specified.

The retrieval of those lidar-derived parameters from Polly ${ }^{\mathrm{XT}}$ measurements and the corresponding error estimation are described in detail by Baars et al. (2016) and En- gelmann et al. (2016) and are based on well established lidar retrievals (Klett, 1981; Fernald, 1984; Ansmann et al., 1992; Murayama et al., 1999). All instrumental effects (deadtime correction, overlap correction, background subtraction) have been considered and the high-quality standards of EARLINET (European Aerosol Research Lidar Network; Pappalardo et al., 2014) have been applied to characterise the instrument.

For the data analysis in this study vertical smoothing lengths between 127 and $457 \mathrm{~m}$ were applied depending on the signal-to-noise ratio. Details are given within the figures. GDAS1 (Global Data Assimilation System) data were used for the data analysis as soundings upon RV Polarstern were only launched once a day during noon. The marine boundary layer top is determined following the procedure described in Baars et al. (2008).

\section{Results}

\subsection{Lidar observations during RV Polarstern cruises across the Atlantic}

The temporal development of the range-corrected signal (i.e. the uncalibrated attenuated backscatter signal) of the autumn transit cruise PS95 is shown in Fig. 2b. RV Polarstern departed on 29 October 2015 from Bremerhaven (Germany) and arrived on 1 December 2015 at Cape Town (Republic of South Africa). The first days of this cruise were characterised by low-level clouds and rain indicated by high signals (white colours). On 9 November $\left(33^{\circ} \mathrm{N}\right)$, the lidar could detect a lofted plume of Saharan dust above the MBL between $600 \mathrm{~m}$ and $3 \mathrm{~km}$ height. From 12 November $\left(24^{\circ} \mathrm{N}\right)$, increasing depolarisation in the MBL could be observed (Fig. 2c) resulting from deposition and down-mixing of dust from higher altitudes. The dust top height decreased from $2.8 \mathrm{~km}$ on 11 November down to $1.5 \mathrm{~km}$ on 13 November. About noon on 14 November 2015, a new dust plume with a lower volume depolarisation ratio and a dust top height of $3.5 \mathrm{~km}$ was observed. RV Polarstern steadily moved towards the equator so that the dust region was left behind in the night from 17 to 18 November $\left(3^{\circ} \mathrm{N}\right)$. After entering the Southern Hemisphere on 19 November, marine stratocumulus clouds occurred frequently. Around noon on 23 November $\left(10^{\circ} \mathrm{S}\right)$, minor traces of dust between 1 and $4 \mathrm{~km}$ could be observed again. Considering HYSPLIT trajectories (not shown), these depolarising layers could consist of dust from the Kalahari Desert. From 24 November $\left(12^{\circ} \mathrm{S}\right)$ onwards, the sky was mostly overcast. At the end of the cruise, on 29 and 30 November, almost pure marine conditions could be observed. The $500 \mathrm{~nm}$ aerosol optical thickness (AOT; Fig 2a), measured with a Microtops sun photometer, ranged around 0.1 on the Northern Hemisphere, increased in the dust-influenced northern tropics to around 0.5 , and decreased below 0.1 in the Southern Hemisphere. 
(a)

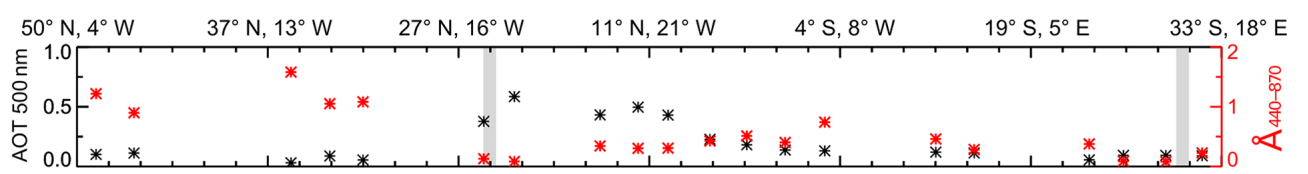

(b)

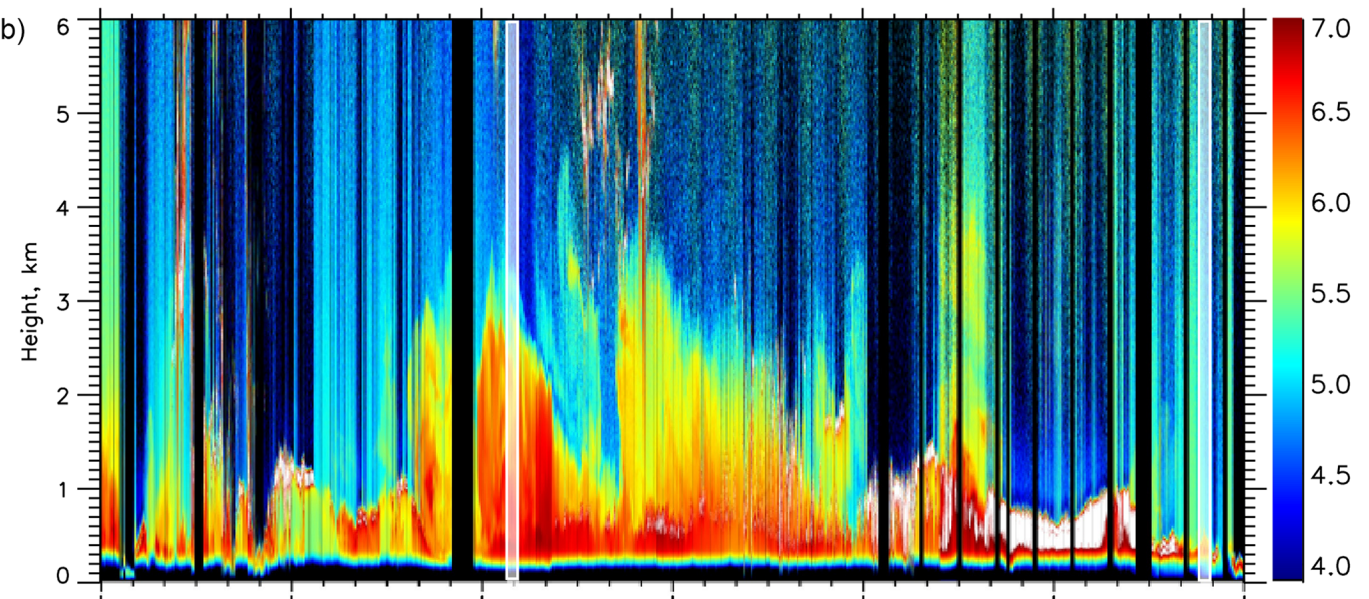

(c)

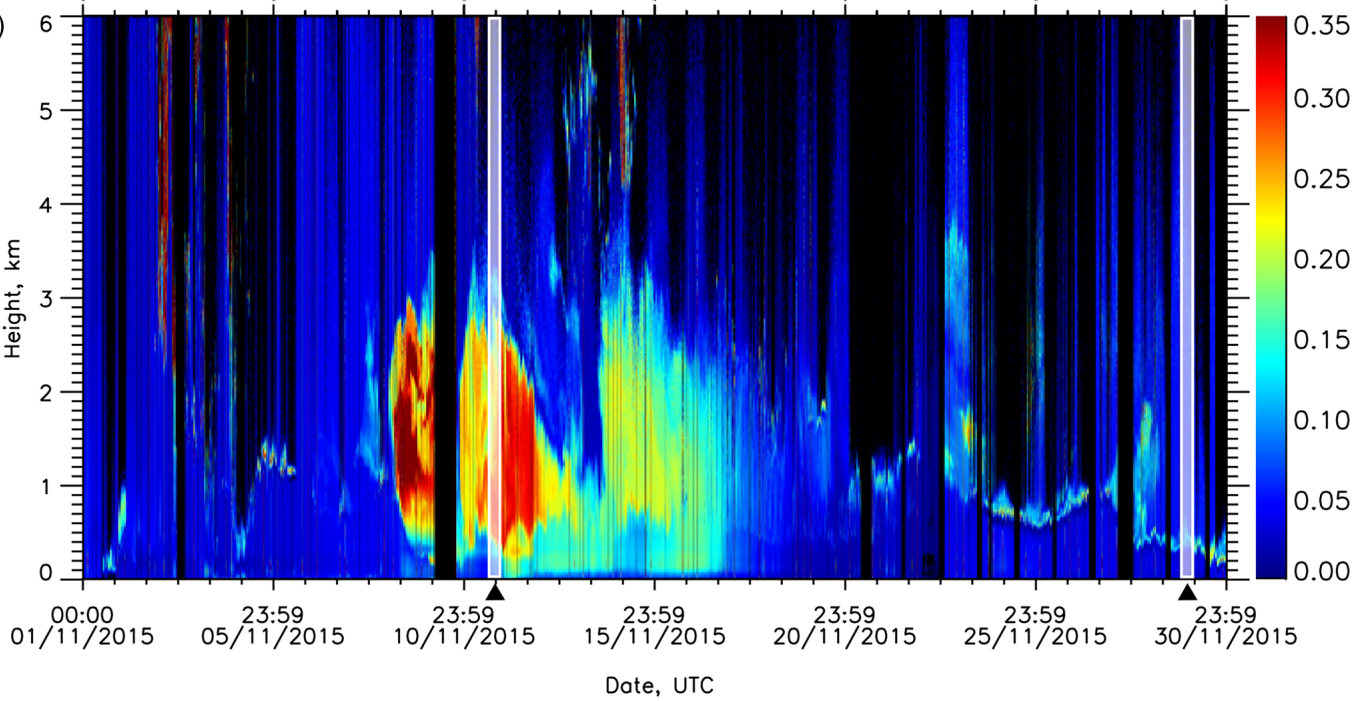

Figure 2. Observational overview of the autumn cruise PS95 from Bremerhaven to Cape Town. Time series of the $500 \mathrm{~nm}$ daily mean AOT and daily mean 440-870 nm Ångström exponent derived with Microtops sun-photometer measurements (a), height-time display of the $1064 \mathrm{~nm}$ range-corrected lidar signal (b), and the volume depolarisation ratio at $532 \mathrm{~nm}$ (c). White bars mark the case studies discussed in Sect. 3.2.

The spring transit cruise PS98 started on 11 April 2016 in Punta Arenas (Chile) and ended on 11 May 2016 in Bremerhaven. Time series of the range-corrected signal and volume depolarisation ratio at $532 \mathrm{~nm}$ are shown in Fig. 3. Because of a failure of the $1064 \mathrm{~nm}$ photomultiplier tube (PMT), no measurements at this wavelength were available. After starting regular measurements in the night from 12 to 13 April, the weather was dominated by clouds. In the night from 14 to 15 April $\left(40^{\circ} \mathrm{S}\right)$, thin depolarising layers at around $2.5 \mathrm{~km}$ could be observed. According to HYSPLIT backward trajectories (not shown), the air mass originated from the Patagonian region; thus, the layers could contain traces of Patagonian dust. Observations on 16 and 17 April were dominated by low clouds and rain. From 22 April $\left(12^{\circ} \mathrm{S}\right)$ to 25 April $\left(4^{\circ} \mathrm{S}\right)$, a lofted dust plume between $1.5 \mathrm{~km}$ and $3.5 \mathrm{~km}$ height could be detected. Crossing the Intertropical Convergence Zone (at around $5^{\circ} \mathrm{N}$ ) on the 27 and 28 April, thunderstorms, rain showers, and clouds with low base heights were predominant. After leaving this region, the lidar observed Saharan dust above the marine boundary layer again. The bottom height of the dust layer decreased from $1.5 \mathrm{~km}$ on 22 April down to around $600 \mathrm{~m}$ on 30 April. In the afternoon of 1 May $\left(23^{\circ} \mathrm{N}\right)$, RV Polarstern left the dust region. After a short stop at the port of Las Palmas (Gran Canaria, Spain) on 3 May, the cruise was continued towards the European continent and the aerosol conditions were more and more influenced by anthro- 


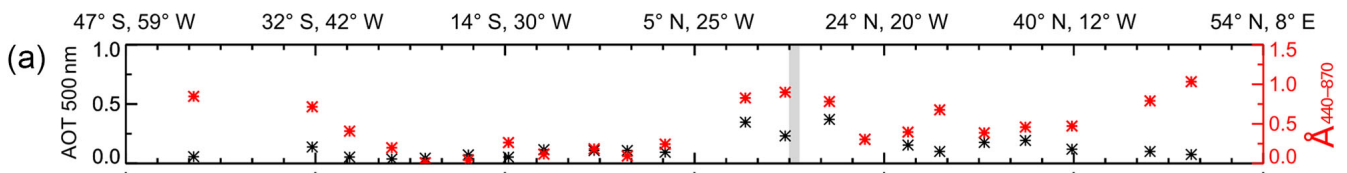

(b)

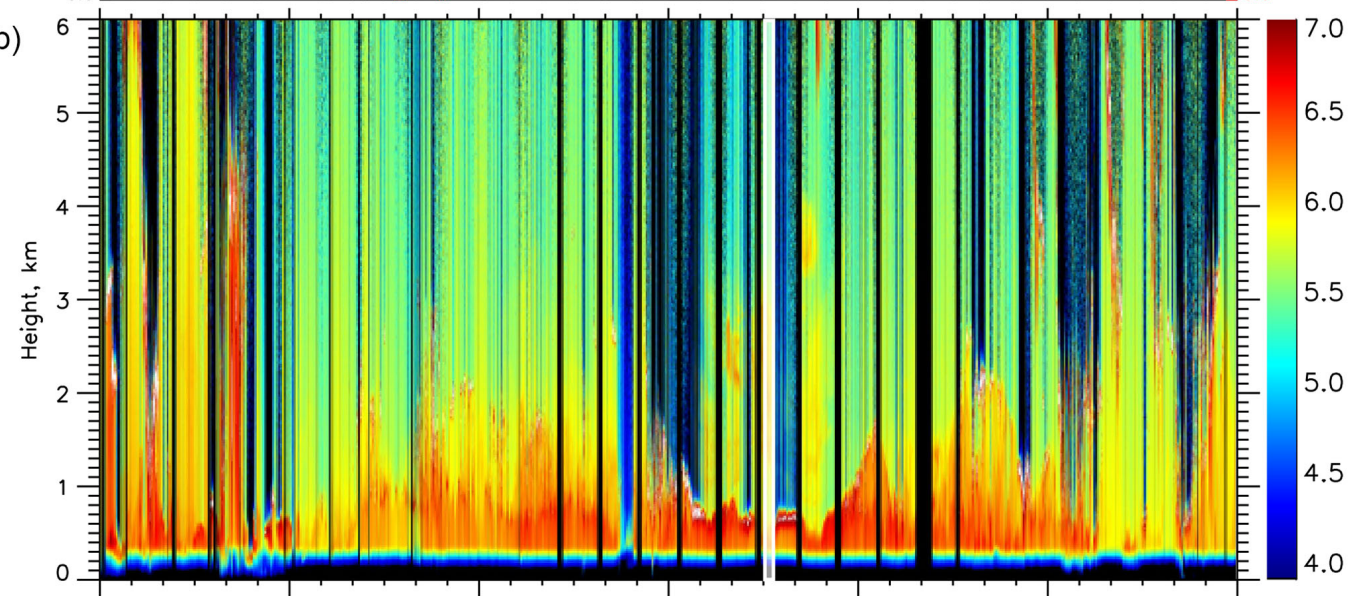

(c)

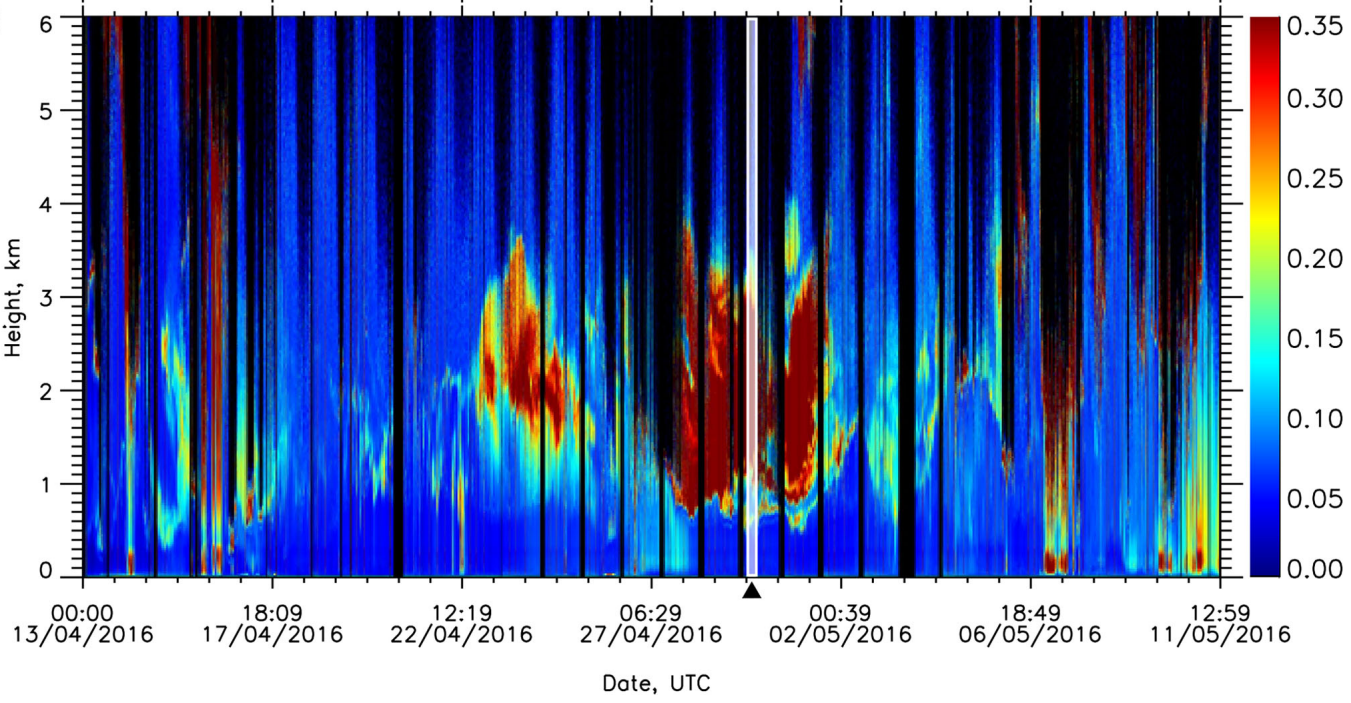

Figure 3. Same as Fig. 2 but for the spring cruise PS98 from Punta Arenas to Bremerhaven. Due to the failure of the $1064 \mathrm{~nm}$ channel, the $532 \mathrm{~nm}$ range-corrected signal is shown in the middle panel. The white bar indicates the time period of the case study discussed in Sect. 3.2.3.

pogenic sources. From 6 May onwards, mostly overcast sky with small cloud gaps was predominant. The AOT at $500 \mathrm{~nm}$ (Fig. 3a) showed a similar zonal behaviour as on the PS95 cruise. The AOT at $500 \mathrm{~nm}$ was below 0.1 in the Southern Hemisphere, except for 17 April, and steadily increased to the maximum of 0.37 on 30 April. After leaving the dustinfluenced region, the AOT ranged between 0.1 and 0.2 in the Northern Hemisphere.

Regular cruises across the Atlantic Ocean from north to south in the northern hemispheric autumn and from south to north in the northern hemispheric spring provided a large amount of lidar data over the Atlantic. Dust has been regularly observed in the northern tropics and subtropics west of the Saharan desert. The AOT at $500 \mathrm{~nm}$, measured with a Microtops sun photometer, has been slightly higher in the Northern Hemisphere than in the Southern Hemisphere, which indicates a higher aerosol load in the former.

\subsection{Case studies}

Three night measurements from PS95 and PS98 were selected to present typical atmospheric conditions by means of a detailed discussion of the optical properties in the MBL and in lofted layers. First, almost pure marine conditions with an overlying dried marine aerosol layer during the autumn cruise PS95 are discussed. Second, a case study on the same cruise but with Saharan dust near the Canary Islands is presented. Third, a case during the spring cruise in 2016 (PS98) with Saharan dust and biomass-burning aerosol mixtures near the Cabo Verde islands is shown. These three case stud- 


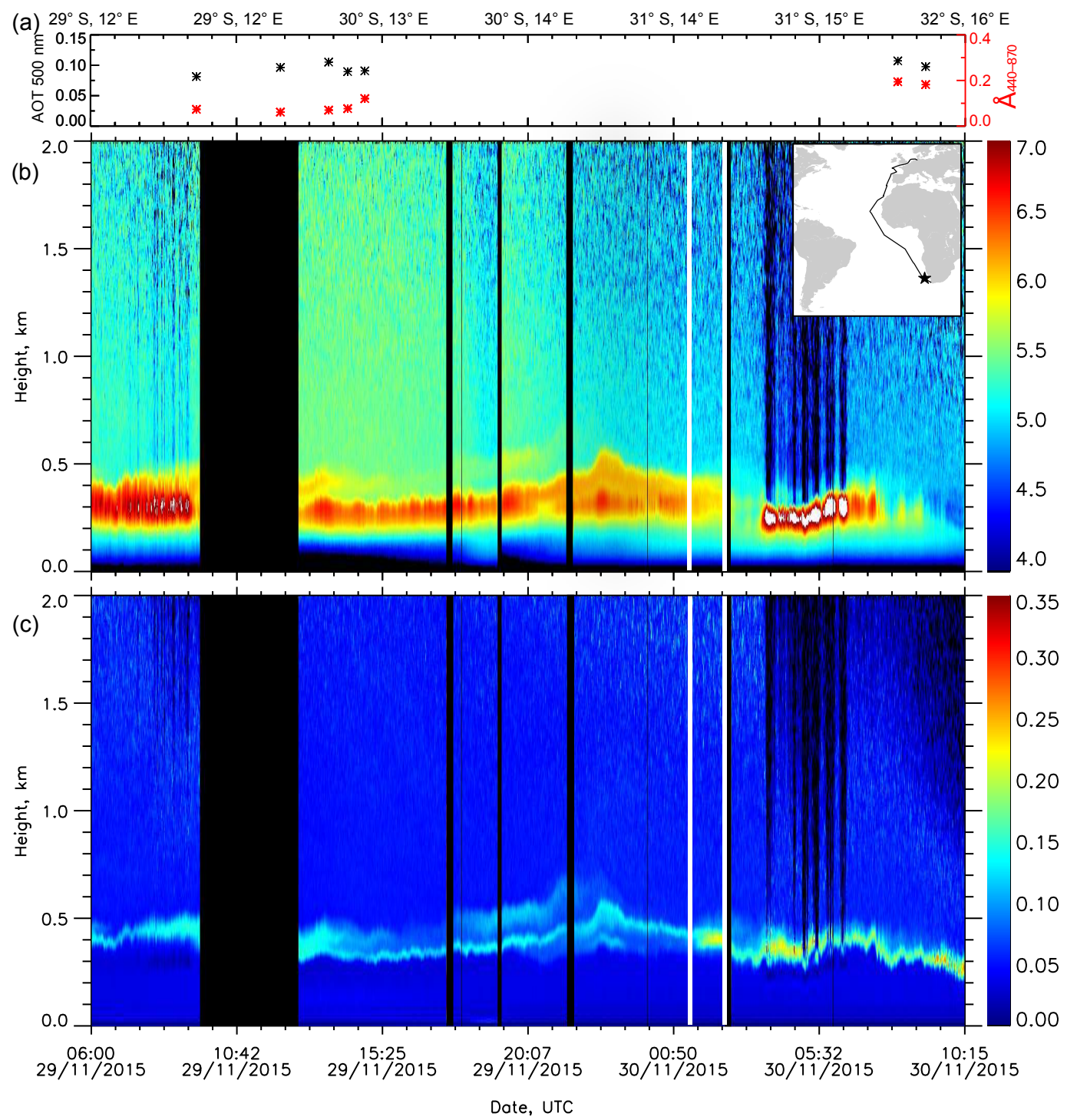

Figure 4. Marine conditions during PS95: time series of the Microtops sun-photometer-derived AOT at 500 and $440 / 870 \mathrm{~nm}$ Angström exponent (a), $1064 \mathrm{~nm}$ range-corrected signal (b), and $532 \mathrm{~nm}$ volume depolarisation ratio (c). Vertical white lines indicate the signalaveraging period for profiles shown in Fig. 5. The black star in the cruise map shows the location of RV Polarstern during this period.

ies are marked with black stars on the cruise tracks (Fig. 1) and with white lines in the cruise overviews (Fig. 2, 3).

\subsubsection{PS95 - marine aerosol conditions}

On 29 and 30 November 2015 at the end of the cruise PS95, clean conditions could be observed near Cape Town. In this area, the dominant aerosol was of marine origin according to CALIPSO aerosol classification (Omar et al., 2009).

In Fig. 4, the time series of the range-corrected signal at $1064 \mathrm{~nm}$ and the volume depolarisation ratio at $532 \mathrm{~nm}$ from 29 and 30 November 2015 are shown. Additionally, the AOT at $500 \mathrm{~nm}$ and the Ångström exponent at 440/870 nm by sun-photometer measurements are shown in the upper panel. Mean AOT at $500 \mathrm{~nm}$ of $0.09 \pm 0.01$ on 29 November $(0.09 \pm 0.02$ on 30 November) and an Ångström exponent of $0.08 \pm 0.02(0.23 \pm 0.08)$ clearly indicate marine conditions for remote oceanic areas, not influenced by continental aerosol sources. In these regions, the AOT at $500 \mathrm{~nm}$ is typically below 0.1 and the Angström exponent less than 0.4 (Smirnov et al., 2006).

The time series of the volume depolarisation ratio (Fig. 4b) shows a thin layer of enhanced depolarisation at the top of the MBL at $300-400 \mathrm{~m}$. This layer consists of dried marine particles and will be discussed later in this section.

Mean profiles of the measured optical properties are shown in Fig. 5 for 30 November 01:15-02:30 UTC. In the right panel, GDAS1 and radio sounding profiles are 


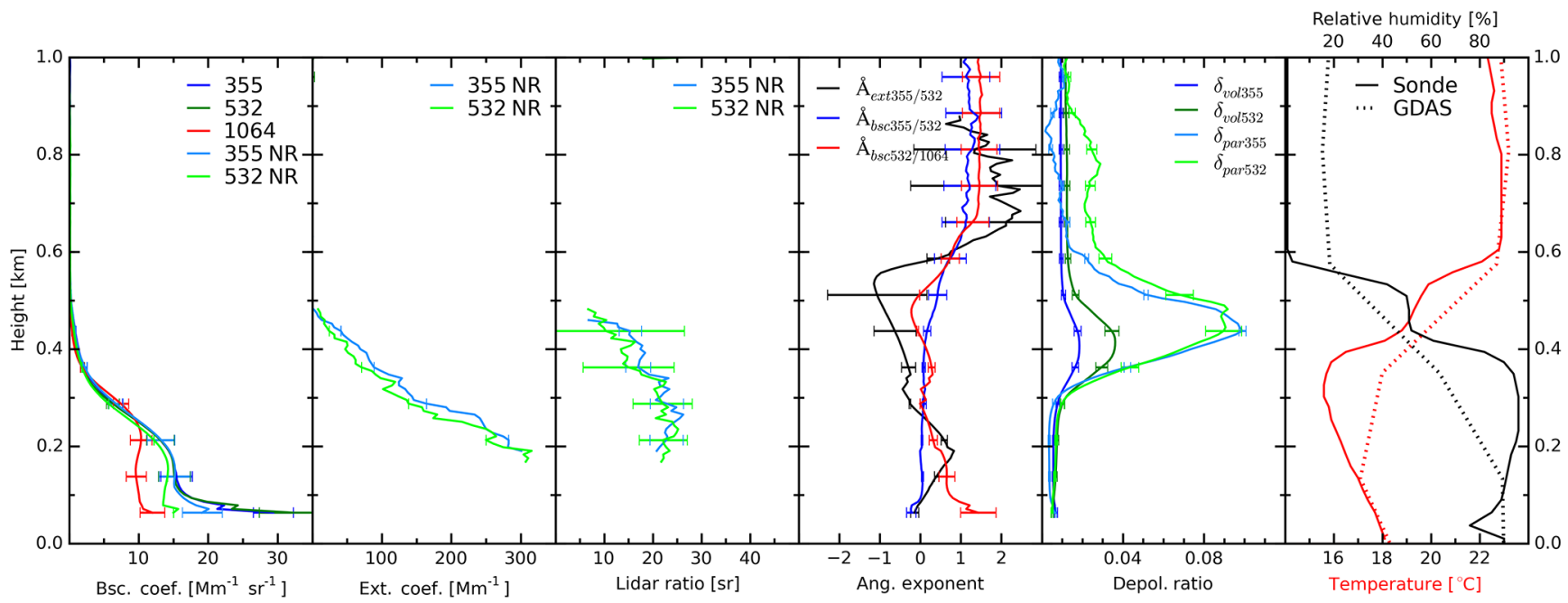

Figure 5. Profiles averaged for 30 November 2015, 01:15-02:30 UTC. Backscatter coefficient and depolarisation ratios are smoothed with $127.5 \mathrm{~m}$ vertical length. Extinction coefficients, lidar ratios, and Ångström exponents are smoothed with 127.5 up to $242 \mathrm{~m}$ and afterwards with $367.5 \mathrm{~m}$. Meteorological data from GDAS1 (30 November 2015, 00:00 UTC) and radio sounding measurements (29 November 2015, 12:00 UTC) are also presented.

shown. The temperature inversion and decrease of the relative humidity (RH) as well as the strong decrease of the backscatter signal (Baars et al., 2008) suggest the MBL top height at about $300 \mathrm{~m}$. Within the MBL, the lidar ratio was $23 \pm 2 \mathrm{sr}$ at 355 and $23 \pm 1 \mathrm{sr}$ at $532 \mathrm{~nm}$, which agrees with results during the second Aerosol Characterization Experiment ACE-2 ( $S_{532} 23 \pm 3$ sr; Müller et al., 2007) and are slightly higher than results of the Saharan Mineral Dust Experiment SAMUM-2a ( $S_{532} 18 \pm 4 \mathrm{sr}$ and $S_{355} 18 \pm 2 \mathrm{sr}$; Groß et al., 2011).

The special highlight in this case study is the increase of the depolarisation ratio at the top of the MBL, whereas the lidar ratio within this layer is low, $16 \pm 1 \mathrm{sr}(355 \mathrm{~nm})$ and $13 \pm 3 \mathrm{sr}(532 \mathrm{~nm})$. Thus, this layer cannot consist of biomass-burning aerosol or dust mixtures. The particle depolarisation ratios at 355 and $532 \mathrm{~nm}$ are around zero in the MBL (large, spherical particles) and increase from 300 to about $450 \mathrm{~m}$, shortly above the MBL top. After this peak, the depolarisation decreases to about zero again. Considering the profiles of relative humidity and temperature, a correlation with the relative humidity is obvious. The relative humidity decreases from about $90 \%$ near the ground to under $20 \%$ above $600 \mathrm{~m}$. In the layer the RH is about $50 \%$ according sounding data and about $40 \%$ according to GDAS1. Simultaneously the temperature increases. HYSPLIT backward trajectories (Fig. 6) indicate that the air parcels arriving at 300,600 , and $1000 \mathrm{~m}$ had only been carried over the South Atlantic Ocean the last 7 days; thus, it can be assumed that the air mass contains mostly marine aerosol, e.g. sea salt. Sea salt aerosol exists as dry particles at low relative humidity. Since sea salt is hygroscopic, the salt particles absorb water to form droplets when the RH exceeds the deliques-

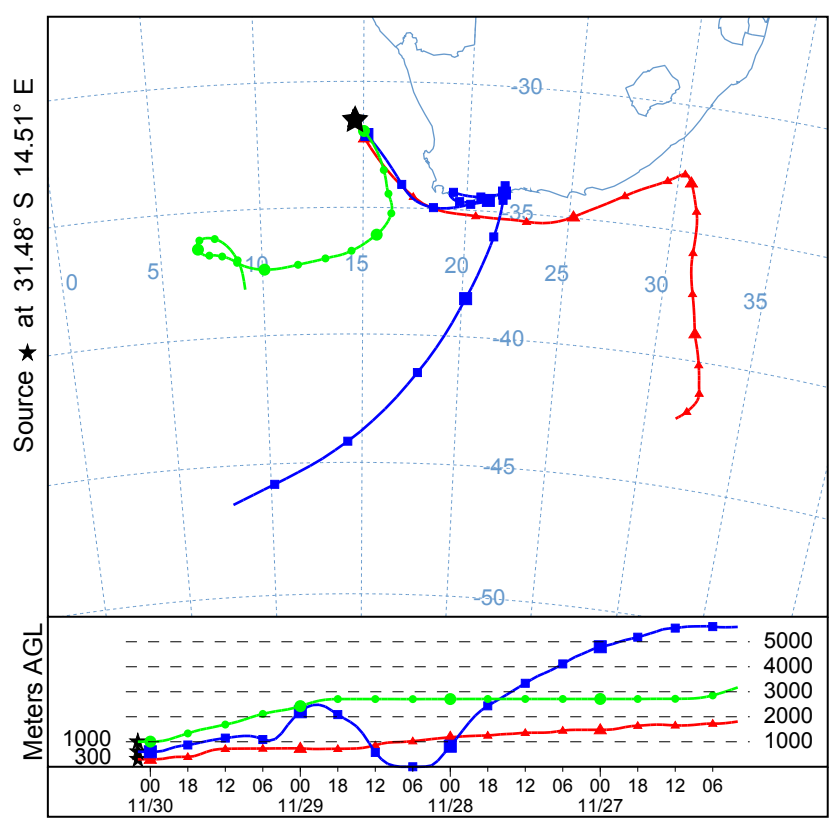

Figure 6. NOAA HYSPLIT backward trajectories for 4 days ending at the position of RV Polarstern $\left(31.48^{\circ} \mathrm{S}, 14.51^{\circ} \mathrm{E}\right.$; marked by the black star) on 30 November 2015, 02:00 UTC, at 300, 600, and $1000 \mathrm{~m}$ a.g.l.

cence relative humidity, which is around $70-74 \%$ depending on the composition of the sea salt (Tang et al., 1997). If the RH decreases to the crystallisation relative humidity (45-48\%; Tang et al., 1997), the particles crystallise from the droplet. At a $\mathrm{RH}$ above the crystallisation relative humidity, the sea salt particles are in solution with water and 
(a)

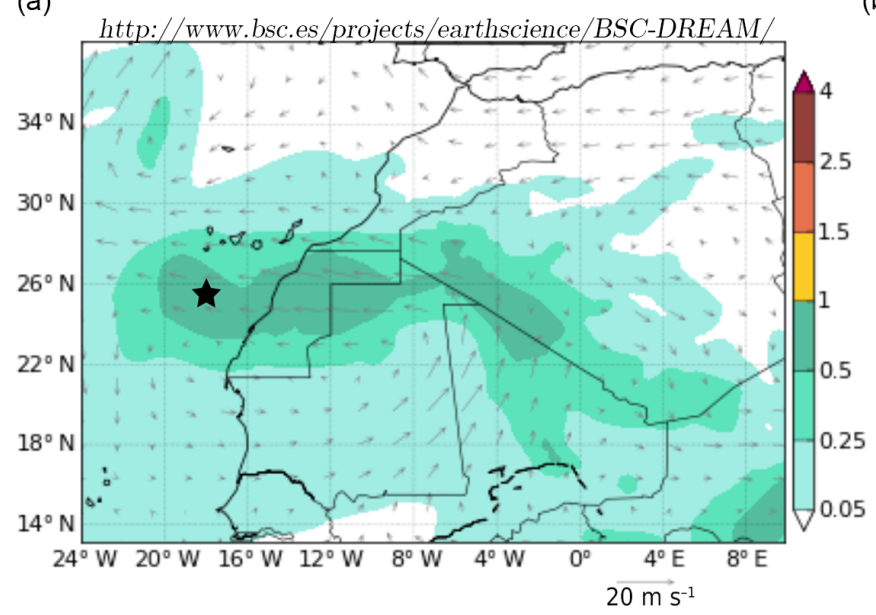

(b)

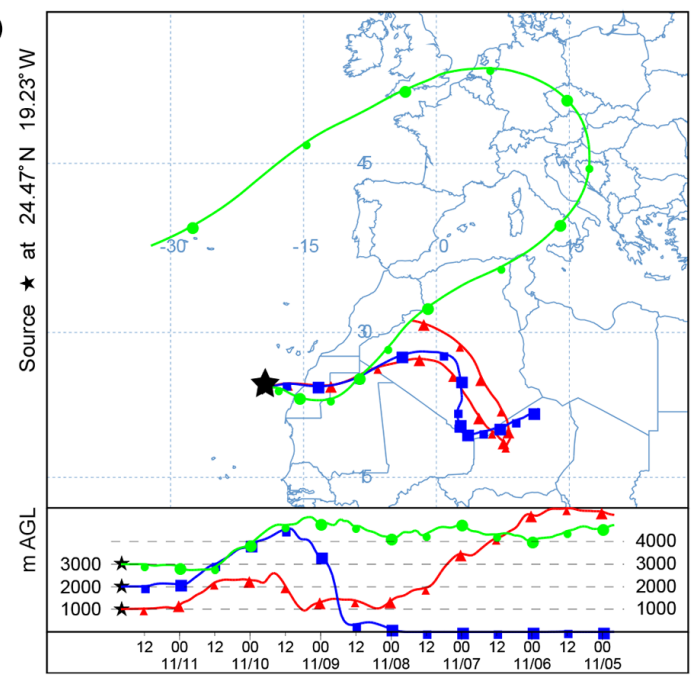

Figure 7. (a) Column-integrated dust concentration $\left(\mathrm{g} \mathrm{m}^{2}\right)$ and $3000 \mathrm{~m}$ wind on 11 November 2015, 12:00 UTC, from the BSCDREAM8b model (Dust Regional Atmospheric Model), operated by the Barcelona Supercomputing Center (http://www.bsc.es/ess/ bsc-dust-daily-forecast, last access: 14 November 2016). (b) The 7-day NOAA HYSPLIT backward trajectories ending at the position of RV Polarstern on 11 November $2015,20: 00$ UTC $\left(24.27^{\circ} \mathrm{N}, 19.23^{\circ} \mathrm{W}\right)$. The position of RV Polarstern is marked by the black star.

show low values of $\delta \approx 3 \%$ (Tesche et al., 2011a). When the RH is below the crystallisation relative humidity, the sea salt particles crystallise and exist as non-spherical particles due to the cubic shape of $\mathrm{NaCl}$, the main constituent of sea salt aerosol (Zieger et al., 2017). As non-spherical particles they cause higher depolarisation ratios. In this case, dried sea-salt particles caused depolarisation ratios up to $9 \%$ at $532 \mathrm{~nm}$ and $10 \%$ at $355 \mathrm{~nm}$. Previous studies showed similar results. Murayama et al. (1999) measured high depolarisation ratios $(\approx 10 \%)$ at $532 \mathrm{~nm}$ in the lower atmosphere associated with sea breeze events in the coastal area of Tokyo Bay. During the Saharan Aerosol Long-range Transport and Aerosol-CloudInteraction Experiment (SALTRACE) winter campaign 2014 at Barbados, Haarig et al. (2017) detected an increase of the particle depolarisation ratio up to $12 \%$ at $355 \mathrm{~nm}, 15 \%$ at $532 \mathrm{~nm}$, and $10 \%$ at $1064 \mathrm{~nm}$ when the RH drops below $50 \%$. Sakai et al. (2000) observed low depolarisation ratios $(<5 \%)$ at $532 \mathrm{~nm}$ over a wide range of relative humidities, whereas $\delta^{\mathrm{par}}>10 \%$ was measured at low $\mathrm{RH}(<50 \%)$ in air masses which had passed over the Pacific Ocean. In a laboratory chamber experiment, Sakai et al. (2010) found linear depolarisation ratios at $532 \mathrm{~nm}$ of $1 \pm 0.1 \%$ for droplets, $8 \pm 1 \%$ for sea salt crystals, and $21 \pm 2 \%$ for $\mathrm{NaCl}$ crystals.

Thus, we can conclude that marine particles were transported above the MBL top, dried, and crystallised and therefore cause a high particle depolarisation ratio even though the backscattering is low compared to the MBL.

This case confirms that marine aerosol can cause depolarisation in the lidar signal when RH is low. Without considering this property of marine aerosol, aerosol layers above the MBL causing depolarisation may be falsely classified. Automatic classification algorithms like the ones for CALIPSO,
EarthCARE, and other lidars should take these feature into account, if relative humidity measurements are available, to not misclassify these aerosols as, for example, mixed dust.

\subsubsection{PS95 - Saharan dust}

When RV Polarstern approached the Canary Islands during the autumn cruise 2015, the first dust plume was observed in the evening of 10 November at around $28^{\circ} \mathrm{N}$. The dust could be measured until 14 November.

Figure 7a presents the column-integrated concentration on 11 November 2015, 12:00 UTC, from the BSC-DREAM8b model, operated by the Barcelona Supercomputing Center. The increased column dust load above the Atlantic at the position of RV Polarstern is illustrated by dark green colour. According to HYSPLIT backward trajectories (Fig. 7b), the air mass measured on 11 November 20:00 UTC originated from the Saharan desert. Only air masses that arrived at $3 \mathrm{~km}$ had been carried also over European areas in the last 7 days.

The range-corrected signal at $1064 \mathrm{~nm}$ and the $532 \mathrm{~nm}$ volume depolarisation ratio of the first dust plume are shown in Fig. 8. Additionally, sun-photometer measurements from 11 and 12 November are given. The sun-photometer-derived Ångström exponent at $440 / 870 \mathrm{~nm}$ is 0.13 on 11 November and 0.08 for the day after. The daily averaged AOT at $500 \mathrm{~nm}$ for these days is 0.38 (11 November) and 0.58 (12 November). The dust layer reached heights about 3 to $3.5 \mathrm{~km}$ on 11 November and slightly descended towards 14 November. From 13 November lofted layers between 2 and $3.5 \mathrm{~km}$ with a lower depolarisation ratio than the first dust plume could be observed. 


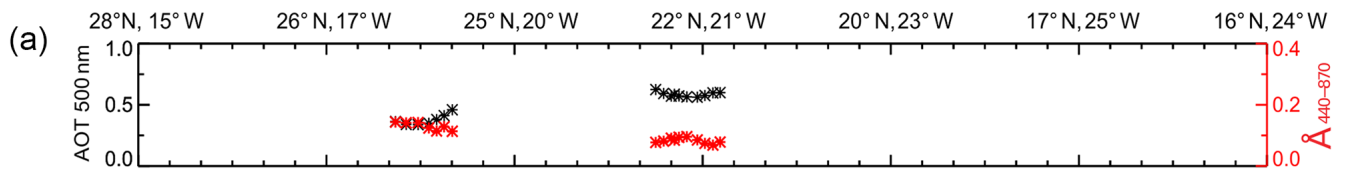

(b)

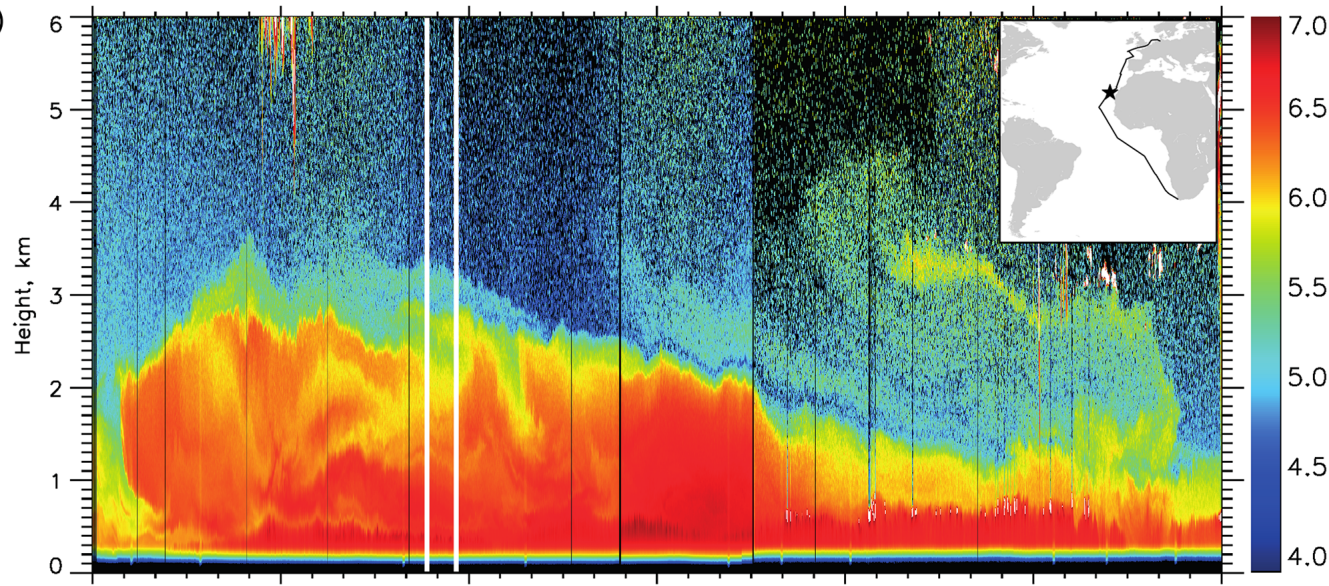

(c)

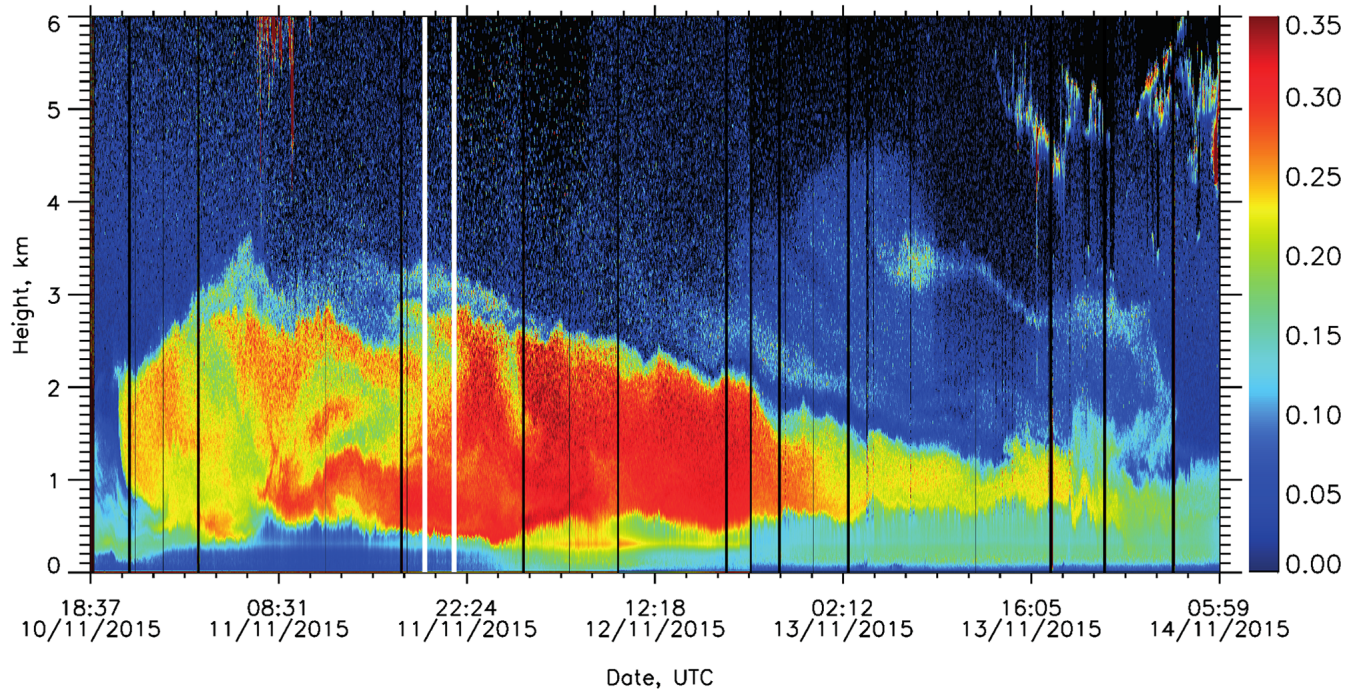

Figure 8. First dust event observed during PS95: time series of the Microtops sun-photometer-derived AOT (500 nm) and 440/870 nm Ångström exponent (a), $1064 \mathrm{~nm}$ range-corrected signal (b), and $532 \mathrm{~nm}$ volume depolarisation ratio (c). Vertical white lines indicate the signal-averaging period for profiles shown in Fig. 9. The black star in the cruise map shows the location of RV Polarstern during this period.

Averaged profiles of the measured optical properties and radio sounding and GDAS1 profiles of temperature and relative humidity are shown in Fig. 9 for 11 November 19:3021:00 UTC (white frame in Fig. 8). Backscatter profiles show an increased backscatter coefficient at all wavelengths from the MBL top (around $400 \mathrm{~m}$ ) up to $2.8 \mathrm{~km}$. The backscatter coefficient at $532 \mathrm{~nm}$ is larger than at $355 \mathrm{~nm}$, whereas the extinction coefficient is wavelength independent. Even though this is an atypical spectral behaviour, comparable observations of higher $532 \mathrm{~nm}$ than $355 \mathrm{~nm}$ backscatter coefficient have already been observed in dust layers near the Cabo Verde islands (Rittmeister et al., 2017), in the eastern Mediterranean at Crete (Tsekeri et al., 2017), and during the SHADOW (Study of SaHAran Dust Over West Africa) campaign in Senegal (Veselovskii et al., 2016). According to Veselovskii et al. (2016), this spectral behaviour may be caused by specific refractive index characteristics induced by the chemical composition of the particles. The mean lidar ratio at $532 \mathrm{~nm}(355 \mathrm{~nm})$ in the height of the lofted aerosol layer is $53 \pm 2 \mathrm{sr}(61 \pm 4 \mathrm{sr})$. The lidar ratio at $355 \mathrm{~nm}$ is higher than at $532 \mathrm{~nm}$, which results from the higher backscatter coefficient at $532 \mathrm{~nm}$ and agrees with values found for dust during the SHADOW campaign (Veselovskii et al., 2016). Consequently, the mean backscatter-related $355 / 532 \mathrm{~nm}$ Ångström exponent is negative $(-0.4 \pm 0.1)$. Negative backscatter-related Ångström exponents are generally found when scattering properties of dust are modelled by assuming a spheroidal shape distribution. The values then 


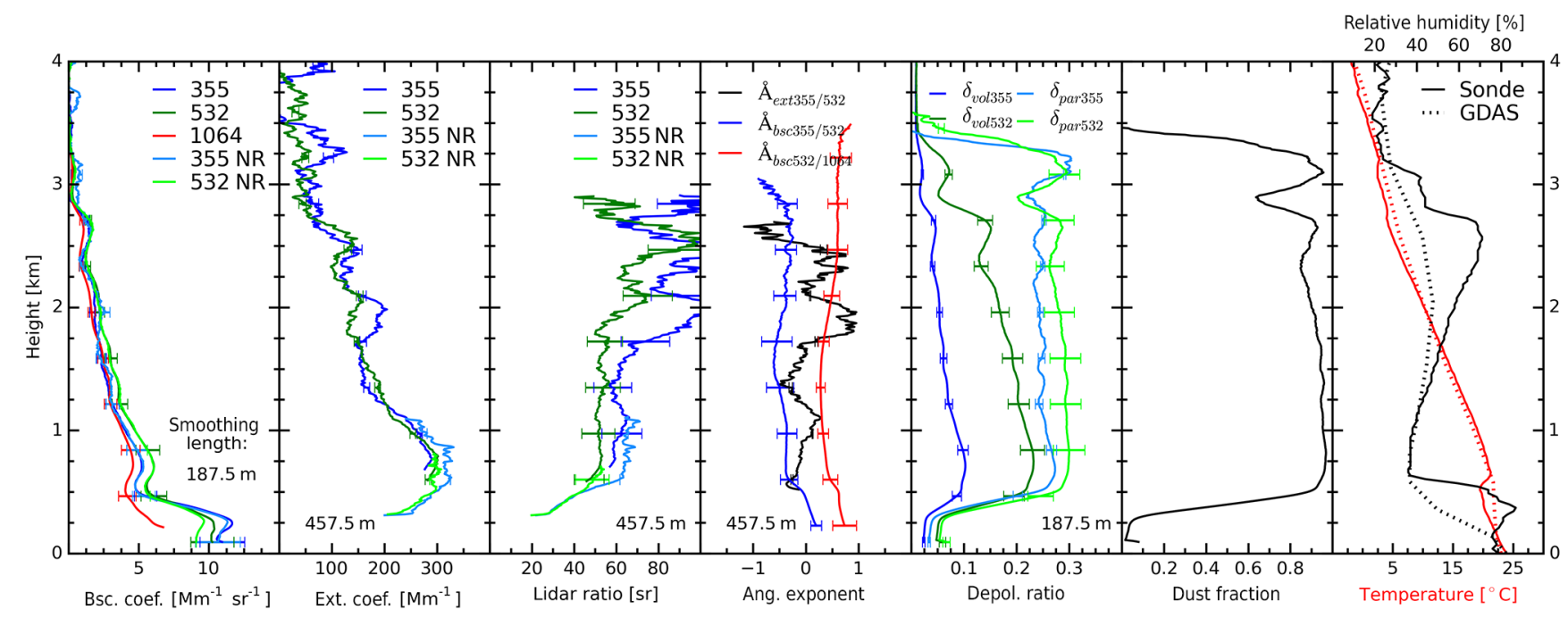

Figure 9. Profiles averaged for 11 November 2015, 19:30-21:00 UTC. Dust fraction calculated following Tesche et al. (2009). Radio sounding profiles from 11 November 2015, 12:00 UTC, and GDAS1 profiles (11 November 2015, 18:00 UTC) are presented in the right panel.

typically vary between -0.5 and -2 depending on the assumptions of the spectral refractive index and the size and shape distributions. The extinction-related Ångström exponent at $355 / 532 \mathrm{~nm}$ of $0.1 \pm 0.5$ and the backscatter-related Ångström exponent at $532 / 1064 \mathrm{~nm}$ of $0.4 \pm 0.1$ are in good agreement with values for dust measured during SAMUM$2 \mathrm{~b}\left(\AA_{\mathrm{ext}}^{355 / 532} \approx 0.22 \pm 0.27, \AA_{\mathrm{bsc}}^{532 / 1064} \approx 0.45 \pm 0.16\right.$; Tesche et al., 2011a). Furthermore, the aerosol layer between $600 \mathrm{~m}$ and $2.8 \mathrm{~km}$ is characterised by a nearly height-constant particle depolarisation ratio of $29 \pm 1 \%$ at $532 \mathrm{~nm}$ and $25 \pm 1 \%$ at $355 \mathrm{~nm}$. The increased particle depolarisation ratios indicate a non-spherical particle shape and are in good agreement with values found for pure dust during SAMUM-2a $\left(\delta_{532}^{\mathrm{par}} \approx 30 \%\right.$ and $\delta_{355}^{\mathrm{par}} \approx 25 \%$; Groß et al., 2011; Tesche et al., 2011a). The fraction of dust and smoke can be estimated using a method described by Tesche et al. (2009). Assuming a $\delta_{532}^{\mathrm{par}}$ of $31 \%$ for pure dust and $5 \%$ for smoke, the fraction of dust in this layer amounts to over $90 \%$ (Fig. 9, panel 6) and can therefore be considered as pure dust.

The MBL reached a height of about $400 \mathrm{~m}$ according to the backscatter profile. Lidar ratios at 532 and $355 \mathrm{~nm}$ are $30 \pm 3$ and $30 \pm 2 \mathrm{sr}$ in the MBL, which are higher than the characteristic values for marine aerosol (see marine case study Sect. 3.2.1) and suggest a mixture of marine aerosol with other particles. Particle depolarisation ratios are also slightly higher, $9 \%$ at $532 \mathrm{~nm}$ and $6 \%$ at $355 \mathrm{~nm}$, and indicate the mixing of dust into the MBL. Therefore, also the MBL is influenced by the frequent dust emission in the Saharan desert.

\subsubsection{PS98 - mixed aerosol layers}

During the spring cruise PS98, extended aerosol layers with enhanced depolarisation were observed near the Cabo Verde islands. The range-corrected signal and volume depolarisa- tion ratio at $532 \mathrm{~nm}$ as well as Microtops sun-photometer measurements on 29 April 2016 are shown in Fig. 10. Sun-photometer measurements determined an average AOT at $500 \mathrm{~nm}$ of 0.23 and an Ångström exponent of 0.9 for $440 / 870 \mathrm{~nm}$.

An increased backscatter coefficient at both wavelengths indicates aerosol layers between 0.9 and $3 \mathrm{~km}$. These layers are separated from the MBL, which reached a height of about $500 \mathrm{~m}$ according to the increased backscatter signal and the GDAS1 and radio sounding data. The mean lidar ratio at $355 \mathrm{~nm}$ is $22 \pm 1 \mathrm{sr}$, the mean backscatter-related $355 / 532 \mathrm{~nm}$ Ångström exponent is $0.9 \pm 0.0$, and the mean particle depolarisation ratios are around zero at both wavelengths in the MBL. These values are indicators of a pure marine boundary layer without dust (see marine case, Sect. 3.2.1).

Mean profiles of the optical properties averaged from 29 April 2016 between 20:15 and 21:00 UTC are shown in Fig. 11. Regarding the backscatter profile, the aerosolladen region above the MBL can be divided into five layers. The layers extend from 0.9 to $1.2,1.3$ to $1.6,1.7$ to 2.2 , 2.3 to 2.5 , and from 2.6 to $3.0 \mathrm{~km}$ and are marked grey in Fig. 11. The $532 \mathrm{~nm}$ near-range extinction coefficient and lidar ratio was not reliable because of a misalignment of the $532 \mathrm{~nm}$ near-range channel which does not affect the Raman backscatter retrievals. The mean lidar ratio in the first layer is $48 \pm 4$ and $46 \pm 9 \mathrm{sr}$ at 532 and $355 \mathrm{~nm}$, respectively. The mean backscatter-related $355 / 532 \mathrm{~nm}$ Ångström exponent is $0.4 \pm 0.1$ and ranges between the typical values of dust $(0.16 \pm 0.45$, SAMUM-2b) and smoke $(0.90 \pm 0.26$, SAMUM-2a; Tesche et al., 2011b). The same applies for the mean particle depolarisation ratio, which is $20 \pm 2 \%$ at $532 \mathrm{~nm}$ and $15 \pm 2 \%$ at $355 \mathrm{~nm}$. These values are in good agreement with values for dust and smoke mixtures measured during SAMUM-2a $\left(\delta_{355,532}^{\mathrm{par}} \approx 16 \%\right.$; Tesche et al., 

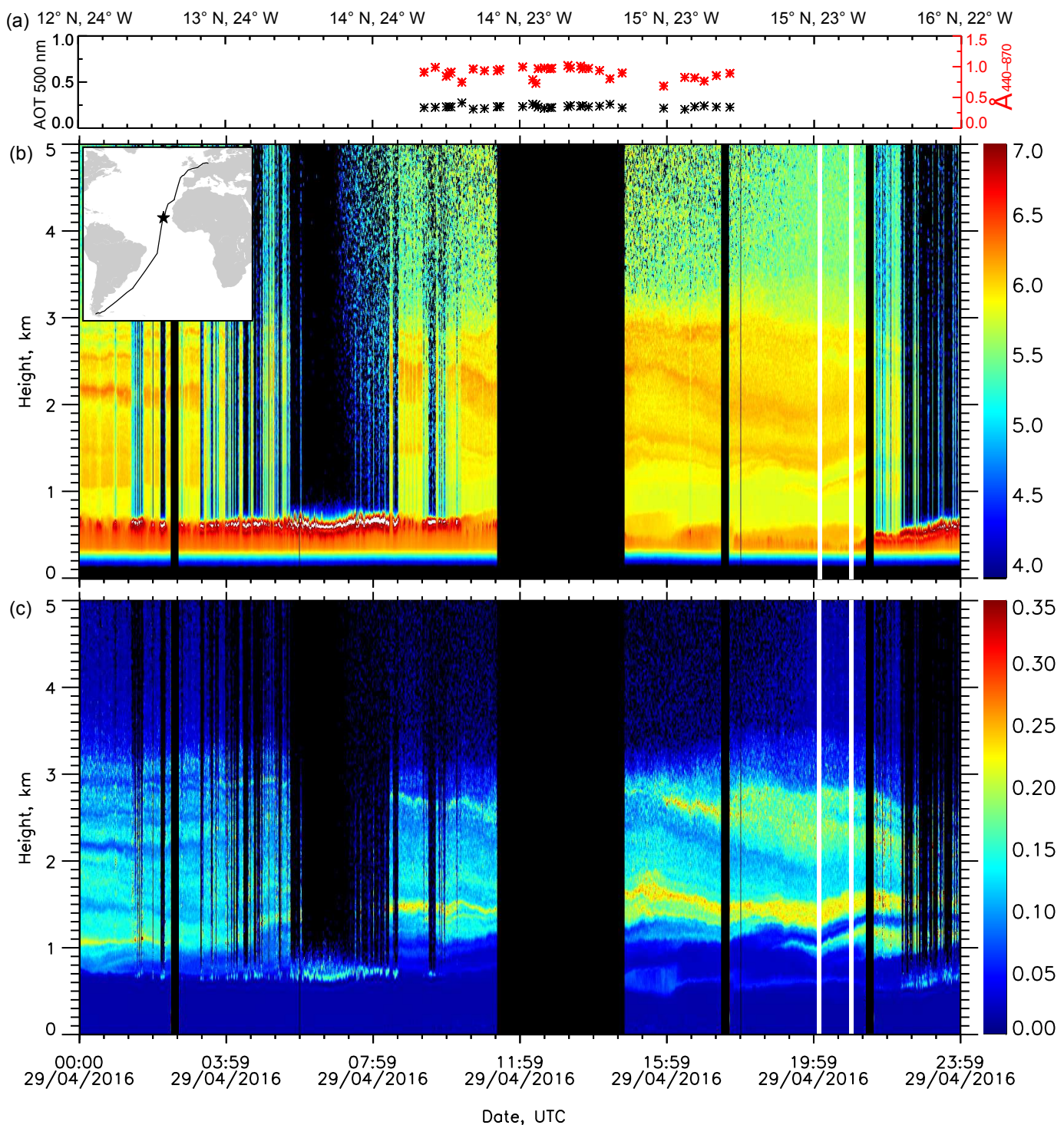

Figure 10. Complex aerosol layering with smoke and dust on PS98: sun-photometer-derived AOT at 500 and $440 / 870 \mathrm{~nm}$ Ångström exponent (a), $532 \mathrm{~nm}$ range-corrected signal (b), and volume depolarisation ratio (c). Vertical white lines indicate the signal-averaging period for profiles shown in Fig. 11. The black star in the cruise map shows the location of RV Polarstern during this period.

2011a) and represent a dust fraction of $63 \%$, applying the method described by Tesche et al. (2009), which is shown in Fig. 11 (panel 6).

The second layer extends from 1.3 to $1.6 \mathrm{~km}$. The mean lidar ratio is $57 \pm 7$ and $63 \pm 8 \mathrm{sr}$ at 532 and $355 \mathrm{~nm}$, respectively. Mean backscatter and extinction-related $\AA$ at $355 / 532 \mathrm{~nm}$ amount $0.1 \pm 0.1$ and $0.4 \pm 0.2$, respectively. The mean particle depolarisation ratio of $24 \pm 2 \%$ at $532 \mathrm{~nm}$ and $19 \pm 2 \%$ at $355 \mathrm{~nm}$ suggests a mixture of depolarising dust and non-depolarising smoke with a dust fraction of $77 \%$ following Tesche et al. (2009).

In the third layer, the mean lidar ratio is $40 \pm 6 \mathrm{sr}$ at $532 \mathrm{~nm}$ and $50 \pm 6 \mathrm{sr}$ at $355 \mathrm{~nm}$. The mean backscatter and extinction-related $\AA$ at $355 / 532 \mathrm{~nm}$ is $0.4 \pm 0.1$ and $1 \pm 0.4$, respectively. This indicates the presence of small, absorbing particles. The particle depolarisation ratio, $13 \pm 1 \%$ at $532 \mathrm{~nm}$ and $9 \pm 1 \%$ at $355 \mathrm{~nm}$, is small compared to the other layers. Therefore, it can be concluded that this layer contains a significant amount of non-depolarising particles like smoke. According to Tesche et al. (2009) the fraction of dust is only around $35 \%$.

Between 2.3 and $2.5 \mathrm{~km}$, in the fourth layer, the particle depolarisation ratio rises again $(18 \pm 1 \%$ at $532 \mathrm{~nm}$, $14 \pm 3 \%$ at $355 \mathrm{~nm}$ ). The mean lidar ratio is $40 \pm 11 \mathrm{sr}$ at $355 \mathrm{~nm}$ and $42 \pm 3 \mathrm{sr}$ at $532 \mathrm{~nm}$. The mean backscatter and extinction-related $\AA$ at $355 / 532 \mathrm{~nm}$ is $0.26 \pm 0.06$ and $0.08 \pm 0.80$. According to Tesche et al. (2009) the fraction of dust in this layer is around $55 \%$. 


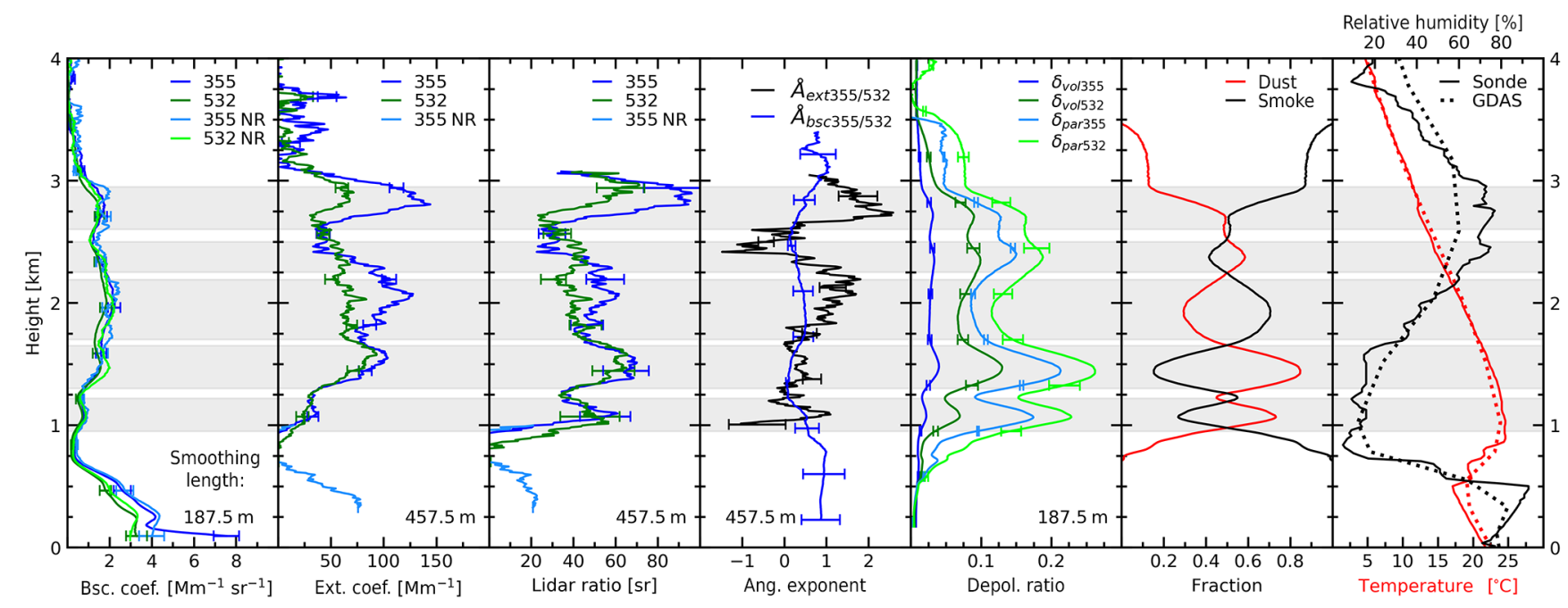

Figure 11. Averaged profiles for 29 April 2016, 20:15-21:00 UTC. Dust and smoke fractions calculated following Tesche et al. (2009). Meteorological data from GDAS1 (29 April 2016, 21:00 UTC) and radio sounding measurements (29 April 2016, 15:00 UTC). Layers are marked grey.

The fifth layer is characterised by a high lidar ratio up to $88 \mathrm{sr}$ at $532 \mathrm{~nm}$ and $68 \mathrm{sr}$ at $355 \mathrm{~nm}$ and high backscatter and extinction-related Ångström exponents of $0.4 \pm 0.2$ and $1.6 \pm 0.6$, respectively. Particle depolarisation ratios decrease with increasing height and amount around $16 \%$ at $532 \mathrm{~nm}$ $(13 \%$ at $355 \mathrm{~nm})$ at the lower edge and $8 \%$ at $532 \mathrm{~nm}(5 \%$ at $355 \mathrm{~nm}$ ) at the top. Using the dust-smoke separation method described by Tesche et al. (2009), the dust fraction decreases from 47 to $14 \%$ within this layer.

Figure 12 presents the HYSPLIT backward trajectories for the last 10 days arriving at the position of RV Polarstern at different altitudes. Air masses arriving in the MBL (500 m) had been carried only over the Atlantic Ocean the last 10 days and therefore contained mostly marine aerosol. Air masses arriving between 1 and $3 \mathrm{~km}$ were advected from the African continent. The air masses arriving at $1 \mathrm{~km}$ height originated from the Saharan desert and passed over active fire areas south-west of the Saharan desert 6 days before arriving at the position of RV Polarstern. Trajectories arriving at 1.5 and $2 \mathrm{~km}$ also passed over the Saharan desert and active biomassburning regions, but have never been close to the ground. As investigated by Nisantzi et al. (2014), fires can support the upward transport of dust into the free troposphere. A high amount of dust in addition to biomass-burning aerosol could therefore also be detected in these altitudes. In contrast, air masses arriving at 2.5 and $3 \mathrm{~km}$ were on ground level over active fire regions for several days and could take up a high amount of biomass-burning aerosol.

During this night measurement, five layers with different fractions of dust and smoke could be detected. At the same time, the MBL was almost pure marine without mixed-in dust or smoke particles. This case study shows that the MBL is not always influenced by dust and smoke transport and dif-

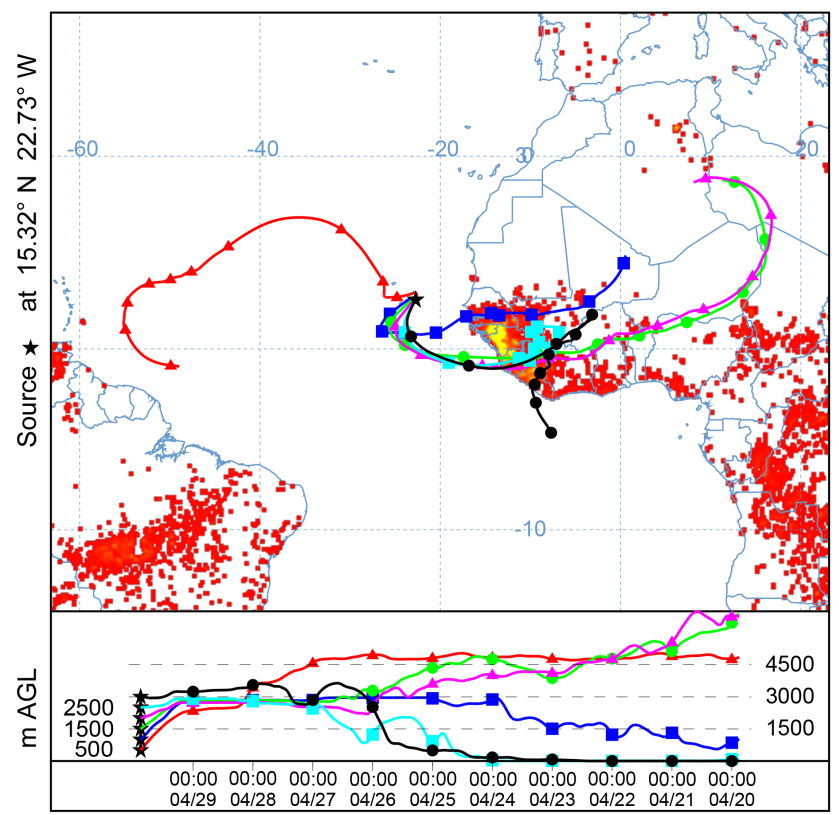

Figure 12. NOAA HYSPLIT backward trajectories ending at 29 April 2016 21:00 UTC at the position of RV Polarstern $\left(15.32^{\circ} \mathrm{N}, 22.73^{\circ} \mathrm{W}\right.$; marked by the black star) at different altitudes. Additionally, fires detected by MODIS on-board the Terra and Aqua satellites are shown. Fires are accumulated over the 10day period from 20 to 29 April 2016. Yellow colour indicates a large number of fires, and red dots indicate a low number of fires in the considered period (https://lance.modaps.eosdis.nasa.gov/firemaps, accessed: 24 February 2017). 

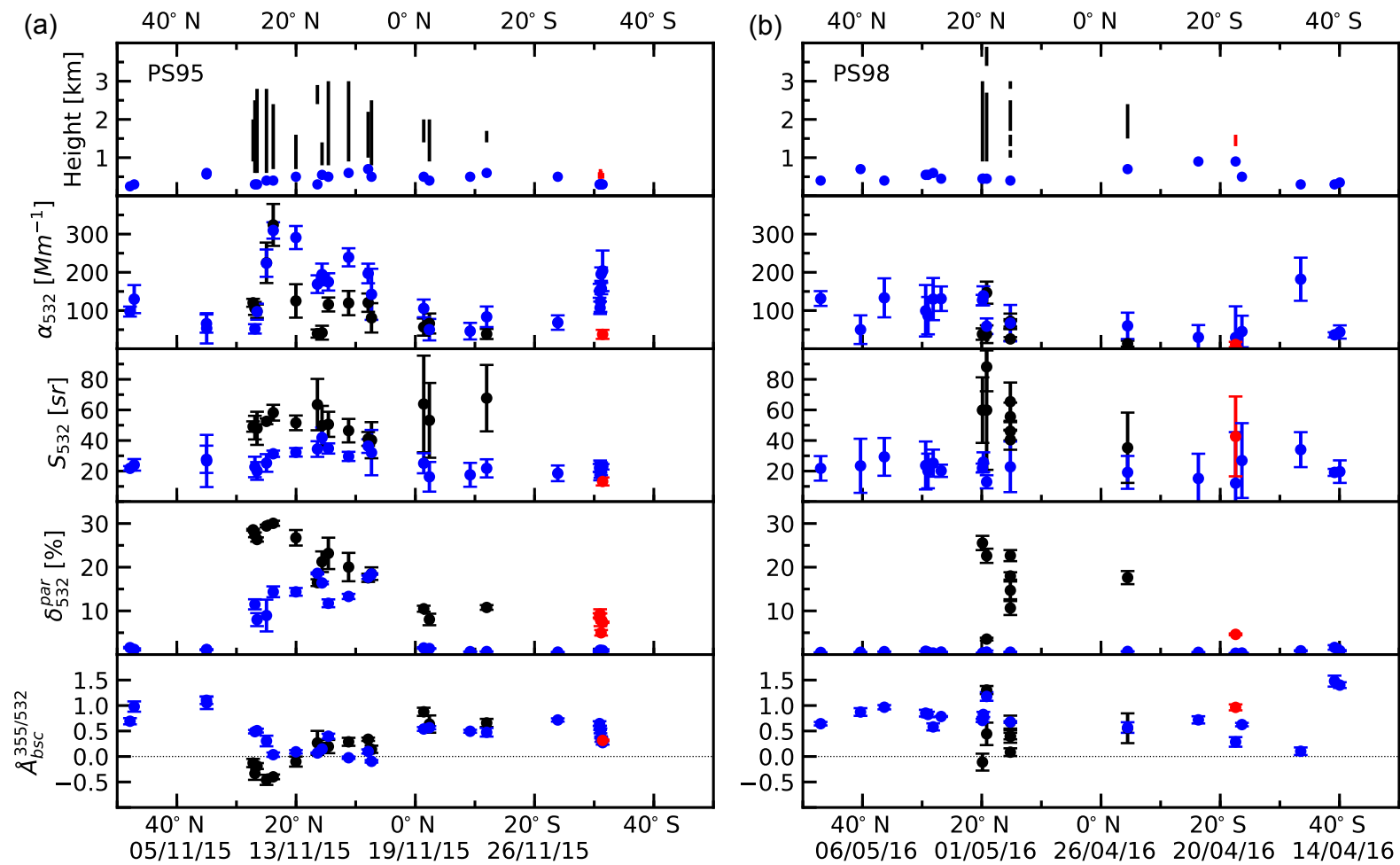

Figure 13. Mean values of extinction coefficient, lidar ratio and particle depolarisation ratio at $532 \mathrm{~nm}$, and the backscatter-related Ångström exponent at 355/532 nm (top down) for MBL (blue), elevated aerosol layers (black), and dried marine layers (red) on PS95 (a) and PS98 (b) from north to south. Error bars indicate the standard deviation. MBL top height and extent of the elevated layers are shown in the first row.

ferent aerosol types can occur at the same time above the Atlantic.

\subsection{Statistical analysis}

A statistical analysis of all Raman measurements with suitable weather conditions and signal quality was performed to provide an overview of latitudinal differences and characteristics of the different aerosol types observed over the Atlantic. A total of 45 night measurements from PS95 and PS98 were selected for analysis with respect to optical aerosol properties. Each measurement was screened for separated aerosol layers. The MBL and, when present, elevated aerosol layers and layers of dried marine aerosol, as presented in the first case study, have been analysed separately. These layers with enhanced depolarisation ratio directly above the MBL will be named dried marine layers.

\subsubsection{Time series}

The MBL top height and the extent of analysed elevated aerosol layers and dried marine layers are shown in the first row of Fig. 13 for PS95 (panel a) and PS98 (panel b), illustrated with blue dots and black and red bars, respectively. The MBL top height ranges between 300 and $900 \mathrm{~m}$ and shows no clear latitudinal trend. Mean values of extinction coefficient, lidar ratio and particle depolarisation ratio at $532 \mathrm{~nm}$, and the backscatter-related Angström exponent at 355/532 nm are shown in the panels below. Blue dots illustrate the MBL mean values derived from near-range measurements. Mean values of the elevated aerosol layers are derived from farrange signals and are illustrated with black dots, whereas mean values of the dried marine layers are illustrated red. These mean values are derived from near-range signals. An exception is the measurement at $22^{\circ} \mathrm{S}$ where the far-range signal is used because of the height of the dried marine layer. Error bars represent the standard deviation. Measurements at $355 \mathrm{~nm}$ are not shown for the sake of clarity but show similar results.

Mean MBL lidar ratios during PS95 are around $25 \pm 3 \mathrm{sr}$ in the northern latitudes and $20 \pm 3 \mathrm{sr}$ in the Southern Hemisphere. In the region of dust, between $35^{\circ} \mathrm{N}$ and the equator, the mean lidar ratio in the MBL is $30 \pm 6 \mathrm{sr}$. The increased lidar ratio is caused by down-mixing of dust from higher altitudes, whereas the lidar ratio in the southern latitudes correlates with pure marine values. Anthropogenic aerosol from the European continent influences the MBL in northern latitudes; the lidar ratio is therefore slightly higher than for a pure marine environment. High particle depolarisation ratios up to $18 \%$ in the MBL confirm the presence of depolarising particles in the region west of the Sahara, while it is below $1 \%$ in the European-influenced North Atlantic and the 
marine-dominated South Atlantic. During PS98, no significant increase of the MBL lidar ratio between $35^{\circ} \mathrm{N}$ and the equator could be observed. The mixing of dust into the MBL is therefore considered to be negligible. This is confirmed by a continuous low particle depolarisation ratio of less than $1 \%$ in the MBL throughout the whole cruise. This contrast to PS95 can be explained by seasonal variations in the dust transport and deposition processes over the Atlantic.

Elevated aerosol layers were mainly observed between $30^{\circ} \mathrm{N}$ and $15^{\circ} \mathrm{S}$ and show a wide range of mean lidar and particle depolarisation ratios, caused by different particle types in these layers. The mean particle depolarisation ratio in elevated layers decreases from around $30 \%$ at $25^{\circ} \mathrm{N}$ towards the south during PS95, which suggests an increasing mixing with other less depolarising particles. At 1 and $12^{\circ} \mathrm{S}$ during PS95 and in the upper aerosol layers at 15 and $19^{\circ} \mathrm{N}$ during PS98, the lidar ratio is higher than the other days (64$88 \mathrm{sr}$ ) while the particle depolarisation is low $(<10 \%)$. This indicates a mixture with other absorbing, non-depolarising particles like biomass-burning aerosol. During PS98 at $5^{\circ} \mathrm{S}$, $2500 \mathrm{~km}$ from the African coast, the lidar ratio between 1.5 and $2.4 \mathrm{~km}$ is around $35 \mathrm{sr}$, which is considerably lower than the characteristic values of pure dust $\left(S_{532} \approx 55 \mathrm{sr}\right.$; Tesche et al., 2011a). This may result from marine aerosol transported upward by turbulent mixing processes (Haarig et al., 2017).

Latitudinal differences can also be seen in the course of the backscatter-related Ångström exponent at $355 / 532 \mathrm{~nm}$ in the MBL during PS95. The mean $\AA_{\mathrm{bsc}}^{355 / 532}$ is around 0 in the dust region, whereas it is around 1 in the northern and 0.5 in southern latitudes. This suggests a mixture of marine aerosol and large dust particles in the MBL between $35^{\circ} \mathrm{N}$ and the equator, whereas in northern and southern mid-latitudes the fraction of smaller particles dominates. In elevated layers, mean $\AA_{\mathrm{bsc}}^{355 / 532}$ ranges between -0.5 and 0.5 . From 30 to $20^{\circ} \mathrm{N}, \AA_{\mathrm{bsc}}^{355 / 532}$ is negative and in the second part of the plume it becomes positive. According to Veselovskii et al. (2016) a low backscatter-related Ångström exponent indicates an increased imaginary part of the refractive index at $355 \mathrm{~nm}$ compared to $532 \mathrm{~nm}$ and therefore a higher absorption at $355 \mathrm{~nm}$ than at $532 \mathrm{~nm}$. This is a result from different aerosol sources and particle properties. During the second cruise, mean $\AA_{\mathrm{bsc}}^{355 / 532}$ ranges between -0.5 and 1.5 . In dusty layers the mean $\AA$ is generally smaller than in the MBL an exception is the upper layer at $19^{\circ} \mathrm{N}$. In this layer, a high amount of small soot particles cause a high Ångström exponent. Ångström exponents in the MBL do not show indications of down-mixed dust during this cruise.

The most prominent feature of dried marine layers is the enhanced particle depolarisation ratio of about 4-9\% compared to the MBL with depolarisation ratios below $3 \%$. Those values are similar to previous observations by $\mathrm{Mu}-$ rayama et al. (1999) and Sakai et al. (2000, 2010). Whereas the lidar ratio in the dried marine layer measured during PS95 is slightly lower than in the MBL, it is about $40 \mathrm{sr}$ in the case measured during PS98 but shows high uncertainty in the latter. Mean Ångström exponents are around 0.5 during PS95 and around 1 during PS98, but do not show a clear difference from MBL mean values.

Differences in optical aerosol properties between northern and southern latitudes and the dust-influenced region west of the Saharan desert were detected. Whereas the Northern Hemisphere is influenced by anthropogenic pollution, southern latitudes are more likely to be influenced by marine aerosols only. Nevertheless, pure marine conditions, not influenced by aerosol originating from the continent, are rare and could only be observed at the end of PS95 near South Africa. Mostly, low-level clouds at the top of the MBL at the southern latitudes prohibited the lidar data analysis and thus the evaluation of more cases of pure marine conditions. In about $65 \%$ of the cruise time in the Southern Hemisphere and $50 \%$ in total during both cruises, clouds along the cruise track did not allow lidar data analysis.

\subsubsection{Optical properties for particle typing}

Mean values of optical properties of the MBL and elevated aerosol layers from PS95 and PS98 (shown in Fig. 13) are discussed to illustrate the potential of aerosol classification using intensive optical quantities. Similar to classifications shown by Burton et al. (2012) and Groß et al. (2015) the lidar ratio at $355 \mathrm{~nm}(532 \mathrm{~nm})$ is presented against the particle depolarisation ratio at $355 \mathrm{~nm}(532 \mathrm{~nm})$ for elevated layers (black), MBL (blue), and dried marine layers (red). Error bars were omitted for the sake of clarity. Coloured ellipses denote the different aerosol categories.

A clear separation of marine and dust-influenced MBL measurements can be seen. Pure marine MBL measurements show lidar ratios between 13 and $40 \mathrm{sr}$ and particle depolarisation ratios less than $2.5 \%$ at 355 and $532 \mathrm{~nm}$, whereas the particle depolarisation ratio of dust-influenced MBL measurements ranges between 5 and $20 \%$, caused by a significant amount of non-spherical particles in the MBL. The lidar ratio within these layers also shows a tendency to higher values with increasing particle depolarisation, caused by dust particles. Elevated aerosol layers can be divided into layers with a high particle depolarisation ratio (20-30\%) and a lidar ratio of about 50-60 sr, layers with a lidar ratio between 30 and $75 \mathrm{sr}$ and a moderate particle depolarisation ratio $(<20 \%)$, and layers with a high lidar ratio $(>80 \mathrm{sr})$ and a low particle depolarisation ratio $(<10 \%)$. The first category is considered for pure dust cases, whereas the mixing with other non-depolarising particles is the second category, named dusty mixtures. These particles could be spherical marine particles or biomass-burning aerosol. If the lidar ratio is higher than reference values of pure dust $(\approx 55 \mathrm{sr})$, the aerosol is considered to be soot; a lower lidar ratio indicates a mixture with marine particles. Layers in the third category with lidar ratios greater than $80 \mathrm{sr}$ and a particle de- 

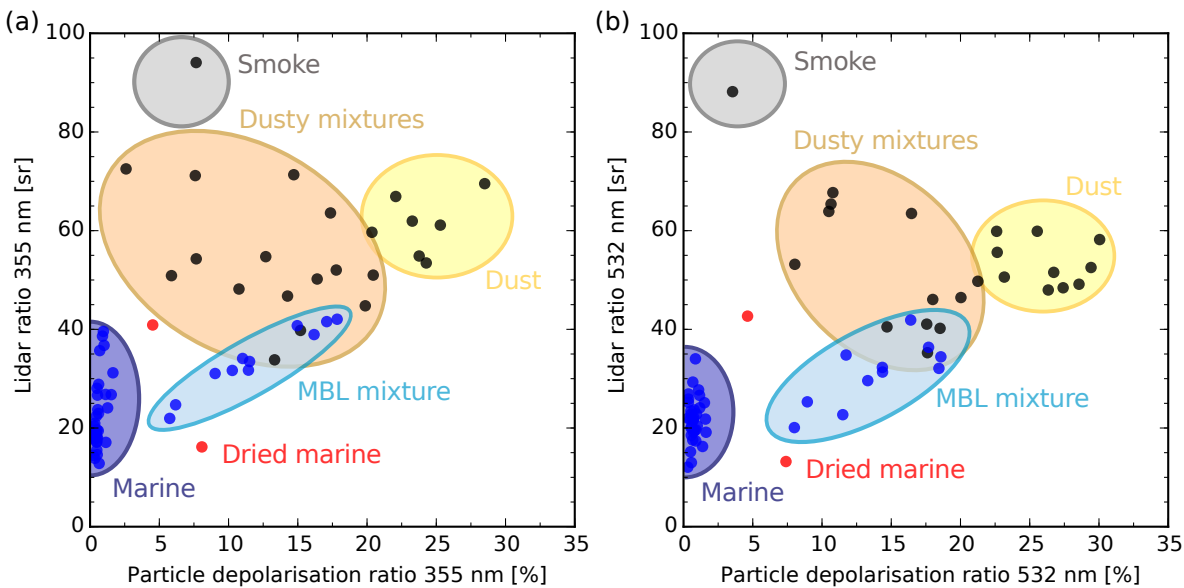

Figure 14. Lidar ratio as a function of the particle depolarisation ratio at $355 \mathrm{~nm}$ (a) and at $532 \mathrm{~nm}$ (b) from all analysed MBL (blue), elevated aerosol layer (black), and dried marine layer (red) measurements of PS95 and PS98. Coloured ellipses denote the different aerosol categories.

polarisation lower than $10 \%$ are considered as smoke dominated. Mean values at 355 and $532 \mathrm{~nm}$ show similar results, although lidar ratios at $355 \mathrm{~nm}$ tend to be slightly higher for all aerosol categories. As clearly seen, some of the mixed aerosol states do overlap and a clear separation by the lidar ratio and depolarisation ratio is not possible.

Therefore, to complete the picture of particle-typedependent optical properties, the backscatter and extinctionrelated Ångström exponents at $355 / 532 \mathrm{~nm}$ and the backscatter-related Ångström exponent at 532/1064 nm are considered for particle type separation in addition to the lidar and depolarisation ratio in Fig. 15. The backscatter and extinction-related Ångström exponent as a function of the particle depolarisation ratio (Fig. 15 bottom face) shows that the Ångström exponent is not a suitable parameter for the separation of pure marine and dust-influenced MBL, while a clear separation is possible considering the depolarisation ratio (pure marine: $\delta^{\mathrm{par}}<5 \%$; aerosol mixtures in the MBL: $5 \%<\delta^{\text {par }}<20 \%$ ). For elevated aerosol layers, a slight tendency towards negative backscatter-related Ångström exponents at $355 / 532 \mathrm{~nm}$ with increasing depolarisation ratio values can be seen (Fig. 15a, c). The extinction-related Ångström exponent at both depolarisation wavelengths is more widely dispersed than the backscatter-related Ångström exponent but shows similar patterns (Fig. 15b, d). In the illustration of the backscatter-related Angström exponent at $532 / 1064 \mathrm{~nm}$ against the particle depolarisation ratio at $532 \mathrm{~nm}$ (Fig. 15e) no tendency to smaller Ångström exponents with higher depolarisation ratio of the elevated aerosol layers can be observed; thus, this parameter is obviously not suitable for a distinction between the different aerosol types. Considering the lidar ratio as a function of the backscatter and extinction-related Ångström exponents (Fig. 15 right face), it again becomes obvious that the Angström exponent is a much less powerful parameter for aerosol typing in a marine environment compared to the lidar ratio and depolarisation ratio.

Resulting from the preceding investigations, we consider the lidar ratio together with the particle depolarisation ratio as best indicators for particle classification above the Atlantic. A clear characteristic in terms of lidar ratio and Ångström exponent for the dried marine layers is not visible. Further observations of those layers are needed to get a comprehensive picture of dried marine aerosol properties.

The values presented above might be valuable information for new aerosol typing schemes needing knowledge from marine areas at the specific lidar wavelengths as, for example, for the upcoming EarthCARE mission. The operated lidar will measure at $355 \mathrm{~nm}$ but also requires information on the spectral behaviour of the optical aerosol properties to obtain radiation closure, which is one goal of this mission.

\section{Conclusions}

Multi-wavelength Raman polarisation lidar measurements from two ship-borne cruises across the Atlantic Ocean (meridional direction) were analysed. Pure marine, pure dust, and dust-smoke mixed conditions were observed. The MBL was often mixed with dust near the equator and northern subtropics, whereas in the outer tropics the marine influence dominated. One highlight was the observation of dried marine aerosol at the top of the MBL, which was relatively often observed during the cruises aboard RV Polarstern but has been rarely reported in literature so far. Dried marine particles cause particle depolarisation ratios up to $9 \%$ correlated with a decreasing relative humidity below $50 \%$. In the northern tropics, west of the Saharan desert, various aerosol layers could be observed during the cruises across the Atlantic from north to south in the frame of the OCEANET project. In addition to a pure Saharan dust plume with a neg- 
(a)

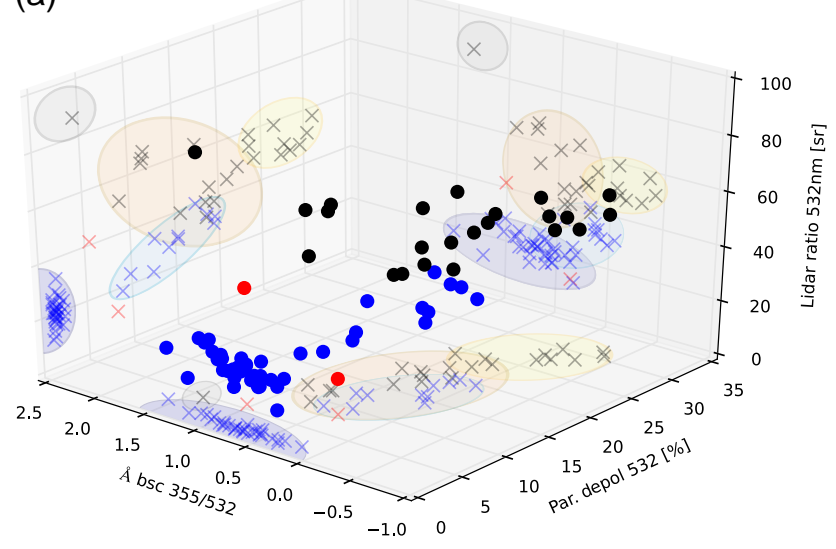

(c)

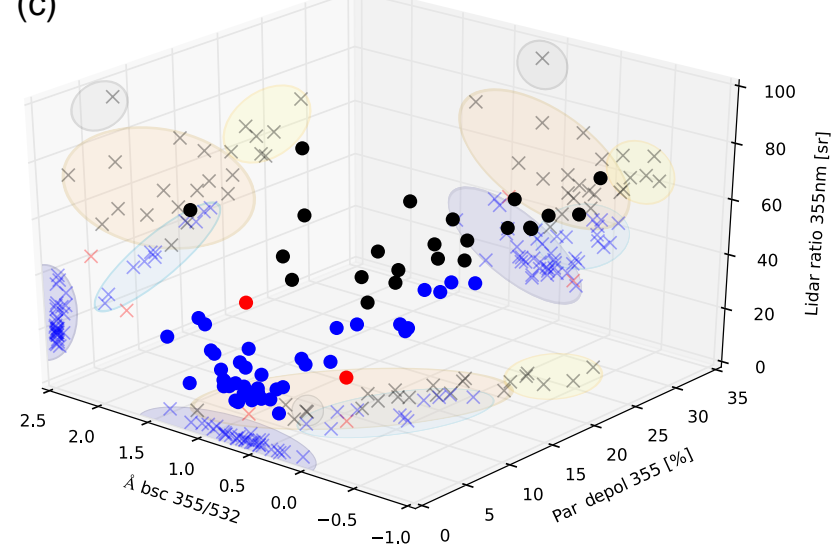

(e)

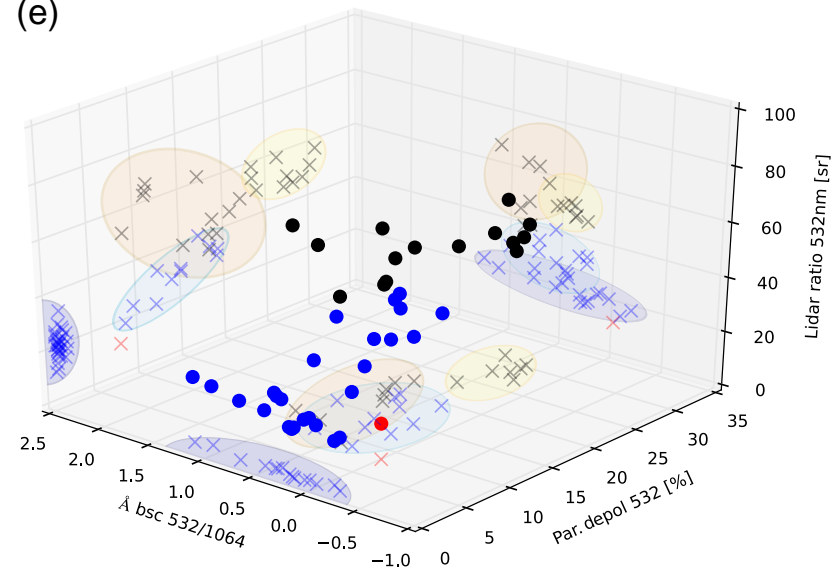

(b)

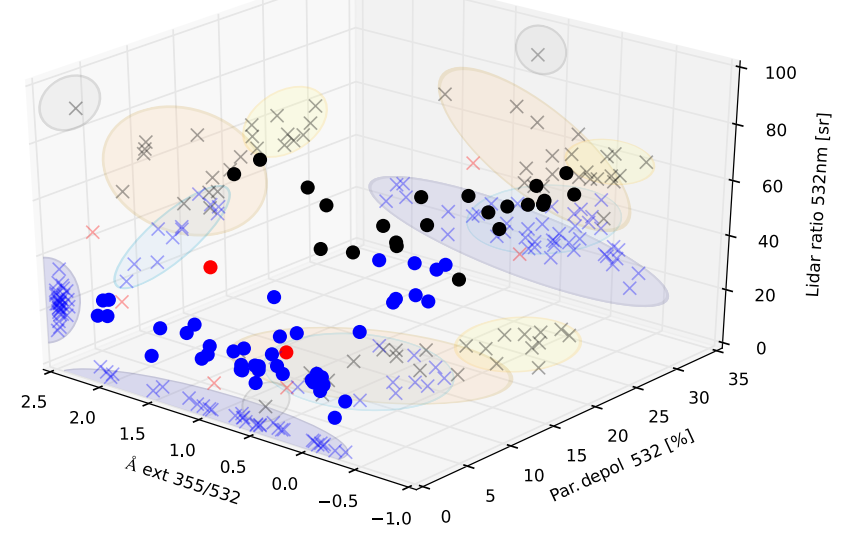

(d)

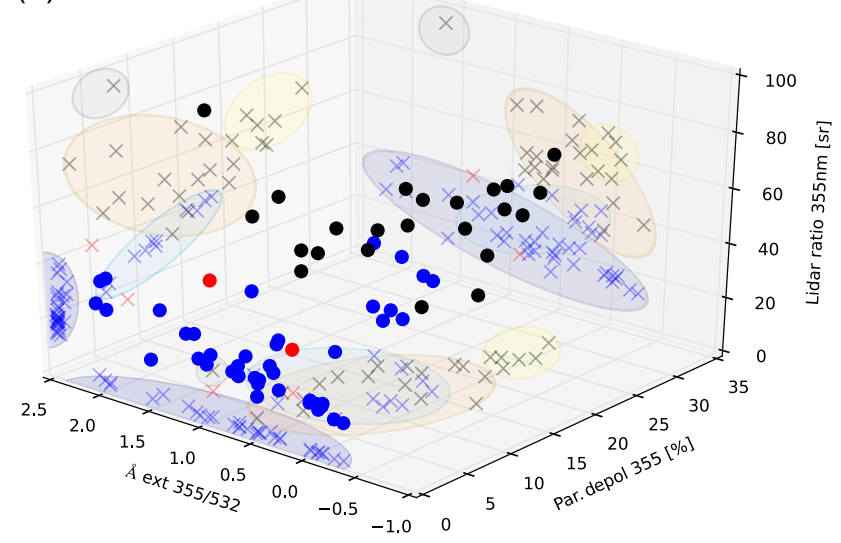

Figure 15. Three-dimensional illustration of the relation between lidar ratio, depolarisation ratio, and backscatter and extinction-related Ångström exponent. Blue dots represent MBL measurements, black dots elevated aerosol layers, and red dots dried marine layers. Coloured ellipses denote the different aerosol categories as in Fig. 14.

ative backscatter-related Ångström exponent of $-0.4 \pm 0.1$ at $355 / 532 \mathrm{~nm}$ near the Canary Islands, Saharan dust layers partly mixed with biomass-burning smoke were observed near the Cabo Verde islands.
A statistical analysis showed latitudinal differences and the potential for aerosol classification of these cruises. Optical properties in the MBL were influenced by down-mixing of dust in the tropics and anthropogenic sources in the northern latitudes. In the Southern Hemisphere, optical properties of the MBL correlate with typical marine values. The mixing 
of dust in the MBL was low, confirmed by a continuous particle depolarisation ratio of less than $1 \%$ in the MBL in the Southern Hemisphere. On both cruises, the MBL top never exceeded $900 \mathrm{~m}$. Elevated aerosol layers were mainly observed in the Northern Hemisphere tropics and reached up to $4 \mathrm{~km}$. Layers of dried non-spherical marine aerosol on top of the MBL could be observed only a few times, since, in about $65 \%$ of the time in southern hemispheric mid-latitudes, lowlevel clouds prohibited the processing of the lidar data for aerosol properties.

All 45 night measurements from PS95 and PS98 were used to illustrate dependencies between lidar ratio, particle depolarisation ratio, and Ångström exponent for the different aerosol types. Lidar ratio and particle depolarisation ratio are the main indicators for the characterisation of the particle types observed over the Atlantic, whereas the Ångström exponent is not a good indicator for aerosol typing. Marine, dust, and smoke aerosols could be clearly identified with particle depolarisation and lidar ratio. But care must be taken when layers of dried marine aerosol occur at the top of the MBL, as the enhanced depolarisation ratio (4-9\%) could lead to wrong conclusions about the mixing state of the aerosol by inferring the presence of mineral dust. We therefore recommend considering the relative humidity and the vertical connection to the marine boundary layer when performing aerosol typing over the ocean, e.g. by space-borne lidars such as CALIOP or EarthCARE.

The values obtained increase the knowledge of the aerosol conditions in marine environments which make $70 \%$ of the Earth's surface. Therefore, the presented results may also be a valuable contribution for the data analysis of satellite retrievals, which are the only instruments able to cover this large part of the Earth at the moment. The obtained data can also be used to validate and further improve model calculations, for example, by evaluation of the height of the different aerosol layers. Nevertheless, future studies are needed to expand the knowledge of dried marine aerosol, its drying processes, and interactions with aerosols above and within the MBL.

Data availability. Meteorological data of all RV Polarstern cruises are available on the Pangaea database (AWI, 2017). For lidar data analysis, GDAS1 (Global Data Assimilation System) height profiles of the National Weather Service's National Centers for Environmental Prediction (NCEP) were used (GDAS, 2018). Trajectories are calculated with the NOAA (National Oceanic and Atmospheric Administration) HYSPLIT (HYbrid Single-Particle Lagrangian Integrated Trajectory) model (HYSPLIT, 2018). The fire data detected by MODIS (Moderate Resolution Imaging Spectroradiometer) that are additionally shown are available at MODIS (2017). BSC-DREAM8b model simulations are operated by the Barcelona Supercomputing Center (BSC DREAM, 2016). AOT data can be downloaded from the AERONET Maritime Aerosol Network (MAN) database (AERONET MAN, 2018). The RV Po- larstern lidar data are available upon request from TROPOS (please contact polly@tropos.de).

Author contributions. SB and HB performed the data analysis and led the manuscript writing. RE, SB, and MR realised the experimental set-up on board the RV Polarstern and were responsible for the lidar measurements. AM initialised the OCEANET project and the corresponding atmospheric measurement on board the RV Polarstern. All authors have contributed to the scientific discussion and the manuscript preparation.

Competing interests. The authors declare that they have no conflict of interest.

Acknowledgements. The authors acknowledge support through ACTRIS under grant agreement no. 262254 and ACTRIS-2 under grant agreement no. 654109 from the European Union's Horizon 2020 research and innovation programme. We thank the Alfred Wegener Institute and the RV Polarstern crew for their incredible effort in making those measurements possible (acknowledgement no. AWI_PS95_00, AWI_PS98_00). Furthermore, we thank the German Weather Service (DWD) for their support during the cruises PS95 and PS98 and appreciate the effort of the AERONET MAN, HYSPLIT, and the Barcelona Supercomputing Center teams to provide additional data.

Edited by: Armin Sorooshian

Reviewed by: Ali Omar and two anonymous referees

\section{References}

AERONET MAN: AERONET Maritime Aerosol Network database, available at: https://aeronet.gsfc.nasa.gov/new_web/ maritime_aerosol_network.html, last access: 15 January 2018.

Albrecht, B. A.: Aerosols, cloud microphysics, and fractional cloudiness, Science, 245, 1227-1230, https://doi.org/10.1126/science.245.4923.1227, 1989.

Althausen, D., Engelmann, R., Baars, H., Heese, B., Ansmann, A., Müller, D., and Komppula, M.: Portable Raman lidar Polly ${ }^{\mathrm{XT}}$ for automated profiling of aerosol backscatter, extinction, and depolarization, J. Atmos. Ocean. Tech., 26, 2366-2378, https://doi.org/10.1175/2009JTECHA1304.1, 2009.

Ångström, A.: On the Atmospheric Transmission of Sun Radiation and on Dust in the Air, Geogr. Ann., 11, 156-166, 1929.

Ansmann, A., Wandinger, U., Riebesell, M., Weitkamp, C., and Michaelis, W.: Independent measurement of extinction and backscatter profiles in cirrus clouds by using a combined Raman elastic-backscatter lidar, Appl. Opt., 31, 7113-7131, https://doi.org/10.1364/AO.31.007113, 1992.

AWI: Meteorological data of RV Polarstern cruises, Pangaea database, https://doi.org/10.1594/PANGAEA.856030, https://doi.org/10.1594/PANGAEA.856031, https://doi.org/10.1594/PANGAEA.861660, last access: 24 February 2017. 
Baars, H., Ansmann, A., Engelmann, R., and Althausen, D.: Continuous monitoring of the boundary-layer top with lidar, Atmos. Chem. Phys., 8, 7281-7296, https://doi.org/10.5194/acp-8-72812008, 2008.

Baars, H., Kanitz, T., Engelmann, R., Althausen, D., Heese, B., Komppula, M., Preißler, J., Tesche, M., Ansmann, A., Wandinger, U., Lim, J.-H., Ahn, J. Y., Stachlewska, I. S., Amiridis, V., Marinou, E., Seifert, P., Hofer, J., Skupin, A., Schneider, F., Bohlmann, S., Foth, A., Bley, S., Pfüller, A., Giannakaki, E., Lihavainen, H., Viisanen, Y., Hooda, R. K., Pereira, S. N., Bortoli, D., Wagner, F., Mattis, I., Janicka, L., Markowicz, K. M., Achtert, P., Artaxo, P., Pauliquevis, T., Souza, R. A. F., Sharma, V. P., van Zyl, P. G., Beukes, J. P., Sun, J., Rohwer, E. G., Deng, R., Mamouri, R.-E., and Zamorano, F.: An overview of the first decade of Polly NET : an emerging network of automated Raman-polarization lidars for continuous aerosol profiling, Atmos. Chem. Phys., 16, 5111-5137, https://doi.org/10.5194/acp16-5111-2016, 2016.

Bösenberg, J., Hoff, R., Ansmann, A., Müller, D., Antuña, J. C., Whiteman, D., Sugimoto, N., Apituley, A., Hardesty, M., Welton, J., Eloranta, E., Arshinov, Y., Kinne, S., and Freudenthaler, V.: Plan for the implementation of the GAW Aerosol Lidar Observation Network GALION, GAW No. 178, 2007.

BSC DREAM: Barcelona Supercomputing Center Dust Daily Forecast, available at: http://www.bsc.es/ess/bsc-dust-daily-forecast, last access: 14 November 2016.

Burton, S. P., Ferrare, R. A., Hostetler, C. A., Hair, J. W., Rogers, R. R., Obland, M. D., Butler, C. F., Cook, A. L., Harper, D. B., and Froyd, K. D.: Aerosol classification using airborne High Spectral Resolution Lidar measurements - methodology and examples, Atmos. Meas. Tech., 5, 73-98, https://doi.org/10.5194/amt-5-732012, 2012.

Eck, T. F., Holben, B. N., Reid, J. S., Dubovik, O., Smirnov, A., O’Neill, N. T., Slutsker, I., and Kinne, S.: Wavelength dependence of the optical depth of biomass burning, urban, and desert dust aerosols, J. Geophys. Res.-Atmos., 104, 3133331349, https://doi.org/10.1029/1999JD900923, 1999.

Engelmann, R., Kanitz, T., Baars, H., Heese, B., Althausen, D., Skupin, A., Wandinger, U., Komppula, M., Stachlewska, I. S., Amiridis, V., Marinou, E., Mattis, I., Linné, H., and Ansmann, A.: The automated multiwavelength Raman polarization and water-vapor lidar Polly ${ }^{\mathrm{XT}}$ : the neXT generation, Atmos. Meas. Tech., 9, 1767-1784, https://doi.org/10.5194/amt-9-1767-2016, 2016.

Fernald, F. G.: Analysis of atmospheric lidar observations: some comments, Appl. Opt., 23, 652-653, 1984.

GDAS: Global Data Assimilation System, meteorological database, available at: https://www.ncdc. noaa.gov/data-access/model-data/model-datasets/

global-data-assimilation-system-gdas, last access: 15 January 2018.

Groß, S., Tesche, M., Freudenthaler, V., Toledano, C., Wiegner, M., Ansmann, A., Althausen, D., and Seefeldner, M.: Characterization of Saharan dust, marine aerosols and mixtures of biomassburning aerosols and dust by means of multi-wavelength depolarization and Raman lidar measurements during SAMUM 2, Tellus B, 63, 706-724, https://doi.org/10.1111/j.16000889.2011.00556.x, 2011.
Groß, S., Freudenthaler, V., Wirth, M., and Weinzierl, B.: Towards an aerosol classification scheme for future EarthCARE lidar observations and implications for research needs, Atmos. Sci. Lett., 16, 77-82, https://doi.org/10.1002/as12.524, 2015.

Haarig, M., Ansmann, A., Gasteiger, J., Kandler, K., Althausen, D., Baars, H., Radenz, M., and Farrell, D. A.: Dry versus wet marine particle optical properties: RH dependence of depolarization ratio, backscatter, and extinction from multiwavelength lidar measurements during SALTRACE, Atmos. Chem. Phys., 17, 1419914217, https://doi.org/10.5194/acp-17-14199-2017, 2017.

HYSPLIT: HYbrid Single-Particle Lagrangian Integrated Trajectory model, backward trajectory calculation tool, available at: https://ready.arl.noaa.gov/HYSPLIT.php, last access: 15 January 2018.

IPCC: Climate Change 2013: The Physical Science Basis. Contribution of Working Group I to the Fifth Assessment Report of the Intergovernmental Panel on Climate Change, Cambridge University Press, Cambridge, UK, New York, NY, USA, 589 pp., 2013.

Kanitz, T., Ansmann, A., Engelmann, R., and Althausen, D.: Northsouth cross sections of the vertical aerosol distribution over the Atlantic Ocean from multiwavelength Raman/polarization lidar during Polarstern cruises, J. Geophys. Res.-Atmos., 118, 2643 2655, https://doi.org/10.1002/jgrd.50273, 2013.

Kanitz, T., Engelmann, R., Heinold, B., Baars, H., Skupin, A., and Ansmann, A.: Tracking the Saharan Air Layer with shipborne lidar across the tropical Atlantic, Geophys. Res. Lett., 41, 1044 1050, https://doi.org/10.1002/2013GL058780, 2014.

Klett, J. D.: Stable analytical inversion solution for processing lidar returns, Appl. Opt., 20, 211-220, 1981.

MODIS: MODIS fire information, available at: https://lance. modaps.eosdis.nasa.gov/firemaps, last access: 24 February 2017.

Müller, D., Ansmann, A., Mattis, I., Tesche, M., Wandinger, U., Althausen, D., and Pisani, G.: Aerosol-type-dependent lidar ratios observed with Raman lidar, J. Geophys. Res.-Atmos., 112, D16202, https://doi.org/10.1029/2006JD008292, 2007.

Murayama, T., Okamoto, H., Kaneyasu, N., Kamataki, H., and Miura, K.: Application of lidar depolarization measurement in the atmospheric boundary layer: Effects of dust and seasalt particles, J. Geophys. Res.-Atmos., 104, 31781-31792, https://doi.org/10.1029/1999JD900503, 1999.

Myhre, G., Samset, B. H., Schulz, M., Balkanski, Y., Bauer, S., Berntsen, T. K., Bian, H., Bellouin, N., Chin, M., Diehl, T., Easter, R. C., Feichter, J., Ghan, S. J., Hauglustaine, D., Iversen, T., Kinne, S., Kirkevåg, A., Lamarque, J.-F., Lin, G., Liu, X., Lund, M. T., Luo, G., Ma, X., van Noije, T., Penner, J. E., Rasch, P. J., Ruiz, A., Seland, Ø., Skeie, R. B., Stier, P., Takemura, T., Tsigaridis, K., Wang, P., Wang, Z., Xu, L., Yu, H., Yu, F., Yoon, J.-H., Zhang, K., Zhang, H., and Zhou, C.: Radiative forcing of the direct aerosol effect from AeroCom Phase II simulations, Atmos. Chem. Phys., 13, 1853-1877, https://doi.org/10.5194/acp13-1853-2013, 2013.

Nisantzi, A., Mamouri, R. E., Ansmann, A., and Hadjimitsis, D.: Injection of mineral dust into the free troposphere during fire events observed with polarization lidar at Limassol, Cyprus, Atmos. Chem. Phys., 14, 12155-12165, https://doi.org/10.5194/acp-1412155-2014, 2014.

Ocko, I. B., Ramaswamy, V., Ginoux, P., Ming, Y., and Horowitz, L. W.: Sensitivity of scattering and absorbing aerosol direct radiative forcing to physical climate factors, J. Geophys. Res.- 
Atmos., 117, D20203, https://doi.org/10.1029/2012JD018019, 2012.

Omar, A. H., Winker, D. M., Vaughan, M. A., Hu, Y., Trepte, C. R., Ferrare, R. A., Lee, K.-P., Hostetler, C. A., Kittaka, C., Rogers, R. R., Kuehn, R. E., and Liu, Z.: The CALIPSO Automated Aerosol Classification and Lidar Ratio Selection Algorithm, J. Atmos. Ocean. Tech., 26, 1994-2014, https://doi.org/10.1175/2009JTECHA1231.1, 2009.

Pappalardo, G., Amodeo, A., Apituley, A., Comeron, A., Freudenthaler, V., Linné, H., Ansmann, A., Bösenberg, J., D’Amico, G., Mattis, I., Mona, L., Wandinger, U., Amiridis, V., AladosArboledas, L., Nicolae, D., and Wiegner, M.: EARLINET: towards an advanced sustainable European aerosol lidar network, Atmos. Meas. Tech., 7, 2389-2409, https://doi.org/10.5194/amt7-2389-2014, 2014.

Rittmeister, F., Ansmann, A., Engelmann, R., Skupin, A., Baars, H., Kanitz, T., and Kinne, S.: Profiling of Saharan dust from the Caribbean to western Africa - Part 1: Layering structures and optical properties from shipborne polarization/Raman lidar observations, Atmos. Chem. Phys., 17, 12963-12983, https://doi.org/10.5194/acp-17-12963-2017, 2017.

Sakai, T., Shibata, T., Kwon, S.-A., Kim, Y.-S., Tamura, K., and Iwasaka, Y.: Free tropospheric aerosol backscatter, depolarization ratio, and relative humidity measured with the Raman lidar at Nagoya in 1994-1997: contributions of aerosols from the Asian Continent and the Pacific Ocean, Atmos. Environ., 34, 431-442, https://doi.org/10.1016/S1352-2310(99)00328-3, 2000.

Sakai, T., Nagai, T., Zaizen, Y., and Mano, Y.: Backscattering linear depolarization ratio measurements of mineral, sea-salt, and ammonium sulfate particles simulated in a laboratory chamber, Appl. Opt., 49, 4441-4449, https://doi.org/10.1364/AO.49.004441, 2010.

Smirnov, A., Holben, B. N., Sakerin, S. M., Kabanov, D. M., Slutsker, I., Chin, M., Diehl, T. L., Remer, L. A., Kahn, R., Ignatov, A., Liu, L., Mishchenko, M., Eck, T. F., Kucsera, T. L., Giles, D., and Kopelevich, O. V.: Ship-based aerosol optical depth measurements in the Atlantic Ocean: Comparison with satellite retrievals and GOCART model, Geophys. Res. Lett., 33, L14817, https://doi.org/10.1029/2006GL026051, 2006.

Tang, I. N., Tridico, A. C., and Fung, K. H.: Thermodynamic and optical properties of sea salt aerosols, J. Geophys. Res.-Atmos., 102, 23269-23275, https://doi.org/10.1029/97JD01806, 1997.

Tesche, M., Ansmann, A., Müller, D., Althausen, D., Engelmann, R., Freudenthaler, V., and Groß, S.: Vertically resolved separation of dust and smoke over Cape Verde using multiwavelength Raman and polarization lidars during Saharan Mineral Dust Experiment 2008, J. Geophys. Res., 114, D13202, https://doi.org/10.1029/2009JD011862, 2009.
Tesche, M., Groß, S., Ansmann, A., Müller, D., Althausen, D., Freudenthaler, V., and Esselborn, M.: Profiling of Saharan dust and biomass-burning smoke with multiwavelength polarization Raman lidar at Cape Verde, Tellus B, 63, 649-676, https://doi.org/10.1111/j.1600-0889.2011.00548.x, 2011a.

Tesche, M., Müller, D., Groß, S., Ansmann, A., Althausen, D., Freudenthaler, V., Weinzierl, B., Veira, A., and Petzold, A.: Optical and microphysical properties of smoke over Cape Verde inferred from multiwavelength lidar measurements, Tellus B, 63, 677-694, https://doi.org/10.1111/j.1600-0889.2011.00549.x, 2011b.

Tsekeri, A., Lopatin, A., Amiridis, V., Marinou, E., Igloffstein, J., Siomos, N., Solomos, S., Kokkalis, P., Engelmann, R., Baars, H., Gratsea, M., Raptis, P. I., Binietoglou, I., Mihalopoulos, N., Kalivitis, N., Kouvarakis, G., Bartsotas, N., Kallos, G., Basart, S., Schuettemeyer, D., Wandinger, U., Ansmann, A., Chaikovsky, A. P., and Dubovik, O.: GARRLiC and LIRIC: strengths and limitations for the characterization of dust and marine particles along with their mixtures, Atmos. Meas. Tech., 10, 4995-5016, https://doi.org/10.5194/amt-10-4995-2017, 2017.

Twomey, S.: The Influence of Pollution on the Shortwave Albedo of Clouds, J. Atmos. Sci., 34, 1149-1154, 1977.

Veselovskii, I., Goloub, P., Podvin, T., Bovchaliuk, V., Derimian, Y., Augustin, P., Fourmentin, M., Tanre, D., Korenskiy, M., Whiteman, D. N., Diallo, A., Ndiaye, T., Kolgotin, A., and Dubovik, O.: Retrieval of optical and physical properties of African dust from multiwavelength Raman lidar measurements during the SHADOW campaign in Senegal, Atmos. Chem. Phys., 16, 70137028, https://doi.org/10.5194/acp-16-7013-2016, 2016.

Wandinger, U.: Introduction to Lidar, in: Lidar: Range-Resolved Optical Remote Sensing of the Atmosphere, edited by: Weitkamp, C., 1-18, Springer, 2005.

Zieger, P., Väisänen, O., Corbin, J. C., Partridge, D. G., Bastelberger, S., Mousavi-Fard, M., Rosati, B., Gysel, M., Krieger, U. K., Leck, C., Nenes, A., Riipinen, I., Virtanen, A., and Salter, M. E.: Revising the hygroscopicity of inorganic sea salt particles, Nat. Comm., 8, 15883, https://doi.org/10.1038/ncomms15883, 2017. 